\title{
Geleneğe Bağlı Yenilikçi Tavrın Kült Bestecisi Cinuçen Tanrıkorur ve Bir Temsili Eser*
}

\section{N. Oya LEVENDOĞLU**}

\begin{abstract}
Cinuçen Tanrıkorur'dan başka kim, milletimizin sözlerden ve seslerden ördüğ̈̈ ezeli taribini 'gemiler geçmeyen bir ummandan' ebediyete taşıyabilirdi...?***
\end{abstract}

\begin{abstract}
ÖZ
Bu çalışma, Cinuçen Tanrıkorur'un yenilikçiliğini, gelenekle ilişkisi üzerinden değerlendirip bestelerinde ve makam kullanımında onu özgün yapan unsurları tespit etmeyi ve Kız Kulesi isimli Buselik Fantezisinde bu unsurların yansımalarını değerlendirmeyi amaçlamaktadır.

Çalışmada, Tanrıkorur'un yakın döneme kadar makam müziği dünyasının içinde bulunduğu gelenekçilik-yenilikçilik çatışmasındaki konumu, süreli yayınlarda girdiği tartı̧̧alara ve kendi yazdığı kitaplardaki metinlerine dayanan söylemleri üzerinden değerlendirilmiştir. Bestelerindeki yenilikçi unsurlar ise B. Reha Sağbaş editörlüğünde hazırlanan Cinuçen Tanrıkorur Beste Külliyatı'nda bulunan tüm eserleri taranarak ortaya çıkarılmıştır. Bu eserler içinde bestecinin yenilikçi ve özgün kimliğini temsilen Kız Kulesi isimli Buselik Fantezisi üzerine bir makam analizi yapılmıştır. Müzikal analizde tercih edilecek analiz türü, Ertuğrul Bayraktarkatal ve Okan Murat Öztürk tarafından yayınlanan "Ezgisel Kodların Belirlediği Bir Sistem Olarak Makam Kavramı: Hüseyni Makamının İncelenmesi” isimli makalede ortaya koyulan ezgi çekirdeği temelli makam analizi modeli (Bayraktarkatal, Öztürk 2012) temel alınarak ve Cenk Güray'ın (2012) “Bin Yılın Mirası, Makamı Var Eden Döngü: Edvar Geleneği” isimli kitabında
\end{abstract}

Bu çalışma, özet haliyle 2018 y1lında düzenlenen İnsan ve Toplum Bilimleri Araştırma Kongresinde sözlü bildiri olarak sunulmuştur.

** Prof. Dr., Erciyes Üniversitesi Güzel Sanatlar Fakültesi Müzik Bölümü Kayseri /Türkiye E-posta:levendogluoya@gmail.com, ORCID: 0000-0002-3397-6961,DOI: 10.32704/erdem.749154 Makale Gönderim Tarihi: 23.10.2019* Makale Kabul Tarihi: 15.04.2020 * (S. ve Edebiyat Mk.)

**** Bestecinin anısına T.C. Kültür Bakanlığ Güzel Sanatlar Genel Müdürlüğü tarafından hazırlanan Geleneği Geleceğe Bağlayanlar: Cinuçen Tanrıkorur isimli CD'ye ait tanıtım kitapçığında Cenk Güray tarafından kaleme alınan metinden alıntılanmıştır. 
açıklanan "sadeleştirme tekniği” kullanılarak gerçekleştirilmiş, eserde kullanılan perdelerin ağırlıkları, ses alanı, merkez perdeleri, merkez ve uydu perdeler arasındaki hareket tipleri çözümlenmiştir. Bu çözümlemelerde makamsal geçkiler ve bu geçkilerin hangi perdeler üzerinde gerçekleştiği de analizlere dahil edilmiş ve bestecinin Buselik makamını işleme biçiminin gelenekle ilişkisi ve yenilikçi vasıfları analiz edilmiştir.

Sonuç olarak geleneğe yüksek sadakatle bağlı kimliği ve keskin uslubu ile kaleme aldığı yazılar Tanrıkorur'un makam müziğini yenileme anlayışının, Osmanlı kimliğine dayalı bir yenilenme olduğunu göstermektedir. Türk musikisinin mevcut durumuna kendisinin de her fırsatta yaptığı eleştirileri, Musiki Mecmuası'nda kaleme aldığı yazılarında görmek mümkündür. Onun makam müziği besteciliğini yenileme biçimi, musiki inkılabı söylemlerinden biri olan yeni musikide "yüksek deyişler"i kullanma vurgusuna da aktif hizmet eden bir içeriğge sahiptir. Yahya Kemal'in şiirlerini Münir Nurettin'in ardından en çok kullanan besteci olarak anılan Tanrıkorur'un besteciliğinde, klasik şiir geleneğinden seçtiği çok sayıda eser bulunmaktadır. Kız Kulesi isimli Buselik fantezi de sözleri itibarıyla bestecinin sıradışı güfte tercihini gösteren ve tasviri eser üretiminde alışılagelmiş konuların dışına çıkma anlayışını temsil eden üretimlerinden bir tanesidir. Tanrıkorur bu yönüyle bir yandan Türk makam müziğine hizmet ederken diğer yandan da Türk kültür tarihine hizmet etmektedir.

$\mathrm{Bu}$ çalışmada analiz edilen eserinde gelenekteki buselik makamını kullanımına bağlı kalmakla birlikte kendi üslubunu ortaya koyan yenilikçi ve özgün nâme yapılarıda kullanmıştır. Geleneksel bestelerde çok fazla görülmeyen, yarı resitatif duyumu sağlayacak tartım yapıları, üçlü aralıkların sık kullanımı, eserin sonunda duyurulan çoksesli düzenlemeler gibi unsurlar da bu eserde Tanrıkorur'un yenilikçiliğini yansıtan yönlerdir.

Anahtar Kelimeler: Cinuçen Tanrıkorur, makam müziği besteciliği, musiki inkılabı, Buselik makamı, makamsal analiz. 


\section{Cinuçen Tanrikorur: The Cult Composer Seeking Tradition-Based Innovation and a Representative Work ${ }^{*}$ \\ ABSTRACT}

This study aims to evaluate Cinuçen Tanrıkorur's innovations in his relationship with tradition so as to identify the unique features in his use of makams, and to analyze the reflections of these features in his Buselik fantasia Kiz Kulesi (Maiden's Tower).

The study also examines Tanrikorur's position in the tradition vs. innovation debate that had, until recently, consumed the world of Turkish makam music, based on the polemical articles he penned for periodical publications and the books he authored. The innovative elements in his works are identified through a review of the Complete Works of Cinuçen Tanrıkorur, edited by B. Reha Sağbaş, and subsequently, Buselik fantasia Kiz Kulesi is selected as representative of the innovative and unique identity of the composer. An analysis of makam is then conducted based on Cenk Güray's (2012) book "Bin Yılın Mirası, Makamı Var Eden Döngü: Edvar Geleneğì" "A Legacy of Thousand Years, the Cycle that Gives Rise to Makam: The Tradition of Adwar"), with particular focus on the percentage of the tones, the sound fields, the central tones, and the types of movements between the central and satellite tones. The makam transitions and the tones through which these transitions are achieved are analyzed, and the way the composer practiced the Buselik makam are examined in terms of its relationship with tradition and its innovative aspects.

In his articles and other writings, which reflect his strong sense of loyalty to tradition and his sharp style, Tanrikorur makes it clear that his approach to innovation in makam music were based on the Ottoman identity, and argues that the musical innovations Atatürk desired were at odds with what actually took place in his era. The articles he penned for Musiki Mecmuası reflect his consistent criticism of the current situation in Turkish music. His style of innovation when composing makam music also meant making active use of "superior expressions", as the discourse of musical reform called for in new music. Tanrikorur was second only to Münir Nurettin in his use of Yahya Kemal's poems as lyrics for his works, and he composed many other works that made use of the tradition of classical poetry. Buselik fantasia Kiz Kulesi is just one of his many works that showcases the

This study was orally presented at the 1st International Congress of Human and Social Sciences Research 
composer's unusual choice of lyrics, and represents the idea of working with unusual topics in the production of descriptive works. As such, Tanrikorur serves simultaneously both Turkish makam music and Turkish cultural history.

In terms of makam, he follows the overall structure of the traditional Buselik makam, supplemented with innovative and original melodies reflecting his own compositional style. Other features of this work that are rare in traditional works and that reflect Tanrikorur's innovative approach include rhythm structures that add a semi-recitative sound, the frequent use of third intervals and, toward the end, polyphonic arrangements.

Keywords: Cinuçen Tanrikorur, composition in makam music, Turk music revolution, Buselim makam, analysis of makam. 


\section{Giriş}

Y

irminci yüzyıl makam müziğine pek çok bileşen üzerinden yön veren Cinuçen Tanrıkorur, Türk kültür ve müzik hayatının yaşamış en mühim şahsiyetlerinden biridir. Osmanlı medeniyetini temsil eden kültür ve sanat alanları ile çocukluğundan itibaren olan irtibatı onun, yaşadığ1 yılların hararetli konularından olan gelenekçilik-yenilikçilik tartışmalarında güçlü bir gelenek savunucusu olarak konumlanmasına neden olmuştur. Tanrıkorur, geleneğe karşı yenilikçiliği Avrupa müziği dünyasının müzik yapma gelenekleri ile özdeş gören zihniyetlerle ateşli söylem savaşlarına girmiş ve yüksek entelektüel kimliği ile bu savaşların kendi dönemindeki belki de en önde gelen aktörü olmuştur. Türk müziği kültür alanı için, onun ud icrasına getirdiği teknik tavır, bestelerinde kullandığı ezgi karakterleri, taksim ve bestelerinde makamları işleme biçimi, Tanrıkorur'un söylemsel alandaki inançlarının icra üzerindeki iz düşümüdür. Yarattığı ekol ile onun icra ve besteleri, geleneğe bağlı bir yenilikçiliğin en çarpıcı örnekleridir. Dini ve lâ dini eserleri ile Tanrıkorur, makam müziği bestecilik alanına yeni bir soluk getirmiştir. Eserlerinde kullandığı nağmelerin, geleneğe bağlı olan ancak bir o kadar da yenilikçi bir kurguyla örülü yapısı, onu diğer besteciler arasında rahatlıkla seçilebilen özgün bir yere oturtmuştur. Geleneksel ezgi yapılarından uzak bir anlayışla ortaya koyduğu üretimlerde, makamı işleme biçiminin Tanrıkorur'un özgünlüğü yaratan en belirleyici vasıf olduğunu rahatlıkla söylemek mümkündür. Beste üretim alanının bağlı olduğu makam kuralları, Tanrıkorur eserlerinde başka bir yansıma bulur ve nazariyata dair bilinen tüm ezberler farklı bir açılımla gelenekten beslenen ancak zaman zaman kulakların aşina olmadığı yeni bir makamsal renge dönüşür. Onun işlediği her makam, hem geleneğe bağlı özellikler taşır hem de adeta yeniden yaratılmı̧̧ gibidir. Eser üretimlerinde tercih ettiği formların kapsamı ve güfte tercihleri geleneğe olan derin sadakatinin en açık örnekleridir. Bununla birlikte makam kullanımında ortaya koyduğu yenilikçi yaklaşımın, ona Cemil misali 'dahi' müzisyen sıfatını verecek bir açılım niteliği gösterdiğini söylemek abartılı olmayacaktır.

Cinuçen Tanrıkorur eserleriyle yeni bir renge dönüşen makam yapılarına ait konular, Türk makam müziğinin kökleri yüzylllara uzanan kadim araştırma alanlarındandır. Nazariyat geleneğine dair bu konularda icrada olup bitenleri anlamak ve açıklamak, mevcut repertuara dayalı eserlerin ve icraların nasıl bir kurama bağlı olarak meydana geldiğini ortaya koymak ise temel meseledir. Bu nedenle yüzyıllar boyunca üstad seviyesindeki besteci ve icracilar, kuramsal alana ait konuları dönüştürüp sürükleyen lokomotif bir rol üstlenmiştir. 
Yirminci yüzyılda Türk makam müziği kuramının gelenekle olan bağlarının büyük ölçüde kopması ve Rauf Yekta öncülüğünde başlayıp Arel-Ezgi-Uzdilek ile yeni bir kuram oluşturulması, bugün hala tartışmalara konu olan sonuçları beraberinde getirmiştir. Bu bağlamda, Cinuçen Tanrıkorur gibi gelenekle bağlarını sıkı tutan ancak bir o kadar da sazında ve bestelerinde son derece özgün yenilikler taşıyan bir sanatçının makam kavrayışına dair zihninde olup bitenler, en somut haliyle bestecinin üretimlerinden izlenebilecektir.

$\mathrm{Bu}$ çalı̧̧ma, Cinuçen Tanrıkorur'un yenilikçiliğini, gelenekle ilişkisi üzerinden değerlendirip bestelerinde ve makam kullanımında onu özgün yapan unsurları tespit etmeyi ve Kız Kulesi isimli Buselik Fantezisinde bu unsurların yansımalarını değerlendirmeyi amaçlamaktadır.

Çalışmada, Tanrıkorur'un yakın döneme kadar makam müziği dünyasının içinde bulunduğu gelenekçilik-yenilikçilik çatışmasındaki konumu, süreli yayınlarda girdiği tartışmalara ve kendi yazdığı kitaplardaki metinlerine dayanan söylemleri üzerinden değerlendirilecektir. Bestelerindeki yenilikçi unsurlar, ömrü boyunca bestelemiş olduğu beşyüzbeş eser içinde, geleneksel anlayıştan farklı olarak kullandığı yapılar üzerinden ortaya çıkarılacaktır. Son adımda ise bestecinin yenilikçiğini ve özgün karakterini temsilen Kız Kulesi isimli Buselik Fantezisi üzerine bir makam analizi yapılacaktır. Müzikal analizde tercih edilecek analiz türü, Ertuğrul Bayraktarkatal ve Okan $\mathrm{Mu}-$ rat Öztürk tarafından yayınlanan "Ezgisel Kodların Belirlediği Bir Sistem Olarak Makam Kavramı: Hüseyni Makamının İncelenmesi” isimli makalede ortaya koyulan ezgi çekirdeği temelli makam analizi modeli (Bayraktarkatal, Öztürk 2012) temel alınarak ve Cenk Güray'ın (2012) “Bin Yılın Mirası, Makamı Var Eden Döngü: Edvar Geleneği” isimli kitabında açılanan "sadeleştirme tekniği” kullanılarak gerçekleştirilecektir. Üç katmanlı bir süreçte yapılacak müzikal analizlerde ilk katman, perdelerin ağırlıklarını ve ses alanını ortaya çıkarmaya yönelik bir uygulamadır. Bu sayede makamın güçlü perdelerini tespit etmek mükün olacaktır. İkinci katmanda eserde kullanılan merkez ve uydu seslerin hareket ilişkileri tespit edilecektir. Bu katmanda eserde kullanılan geçkiler, bu geçkilerin hangi perdeler üzerinde gerçekleştiği ortaya çıkacaktır. Bu analiz sürecinin ardından, Tanrıkorur'un Buselik makamını işleme biçiminin, geleneksel yapı ile ilişkisi değerlendirilecektir. Üçüncü katmanda ise güfte ve nâme ilişkisi incelenecektir.

\section{Tanrıkorur Söylem ve Uygulamalarında Müzikte Kimlik ve Yenilikçilik}

Bu çalı̧̧mada Cinuçen Tanrıkorur'un fikir dünyası özelinde değerlendirilecek olan Türk makam müziğine dair gelenekçilik-yenilikçilik ve millî kimlik 
tartışmalarının geçmişi, Osmanlı sarayının ve entelektüellerinin, batılılaşmaya yönelik fikir tartışmalarına kadar uzanır. Yaklaşık ikiyüz yıllık bir süreç eşliğinde oluşan bir alt yapının, Cumhuriyet döneminin modernleşme sürecinde çok daha etkin bir uygulama alanı bulduğu ve makam müziği için bu dönemin gerek kuramsal alandaki çalışmalarda gerekse eğitim programlarındaki yaptırımlarda tam bir kırılma dönemi yaşadığı, son dönem çalışmalarında ağırlıkla yer tutan bir konu haline gelmiştir. Bu dönemde olup bitenlere bakıldığında Avrupa müziğinin ülkede hızla yaygınlaşmasına yönelik politikaların, Türk müziği-Batı müziği taraftarlarını gelenekçilik ve yenilikçilik noktasında kutuplaştırıp, makam müziği dünyasını da kendi içinde böldüğü görülür (Ayas 2014; Ayas 2018).

Yirminci yüzyılın ilk çeyreğinden itibaren böylesine bir ortamda açılan müzik eğitimi kurumlarında da ülkemizdeki bu çağdaşlaşma sancılarının izleri açıkça görülmektedir (Levendoğlu 2018). Dönemin musikişinaslarını etkisi altına alan yeni müzik kimliğimiz üzerine yürütülen tartı̧malarda Musa Süreyya Bey, Ali Rıfat Çağatay, Rauf Yekta Bey, Hüseyin Saadettin Arel, Cemal Reşit Rey, Adnan Saygun, E. Zeki Ün gibi iki kanadın önde gelen isimleri, bugünün Türk makam müziği dünyasına bağlanan, çatışmalarla dolu ve söylemsel alanda adeta kalemşörlük üzerinden yürüyen bir hikayenin temsilcileri olmuşlardır. Günümüz besteci ve icracılarına bu silsile ile naklolan fikir tartı̧̧malarında ise gerek söylemleriyle gerekse uygulamaya dönük her tür hamlesiyle, makam müziğini millî kimliği ile yenileyecek unsurların kendi içinde barındığını savunan en güçlü figürlerden biri Cinuçen Tanrıkorur olmuştur.

Geleneğe yüksek sadakatle bağlı kimliği ve keskin uslubu ile kaleme aldığ1 yazılarda "Ezikliğimiz soruyor: Sizin konserlerinize yabancilar da geliyor mu?", "Papyonlu Folklor", "Çıngıraklı Mehter", "When Are We Going to Zikir Again?", "Skandalın Hikmeti", "Maşallah Devlet Sanatçıma" (Tanrıkorur 2001) gibi kullandığı başlıklar, dönemin psikolojisine gösterdiği tepkinin ve eleştirilerinin özeti gibidir. Onun makam müziğini yenileme anlayışı, Osmanlı kimliğine dayalı bir yenilenmedir. Ancak bu müziğin temsiliyetindeki durumun eleştirisini de her firsatta yapar ve Atatürk'ün musikideki yenilenme hayalinin de bu yapılanları kastetmediğini hem konuşmalarında hem yazılarında sıklıkla dile getirir. Bu konudaki savunmaları içinde Atatürkçü bir müzik politikasının nasıl anlaşılması gerektiğine dair görüşünü,

Tanrıkorur'un bu yazısı, 1996'daki Cumhuriyet kutlamalarında Hikmet Şimşek'in yöneteceği bir orkestra ve koro konserinden vazgeçilip Kültür Bakanlı̆̆1 Devlet Klasik Türk Müziği Korosu’nun konser vermesine karar verilmesi nedeniyle Hikmet Şimşek'in sarfettiği "işte müzikte irtica budur" ve "...sanat ve Cumhuriyet açısından skandaldır" sözlerine cevaben yazılmıştır. 
Ulu Önder'in 1934 Kasım'ında Meclis'te sarfettiği sözleri temel alarak ifade eder. Tanrıkorur'a göre Atatürk'ün meclis konuşması şu üç manaya gelir (Tanrikorur 1978: 16). İlki;

Önce musikinin değişmesi yeni değiş̧ikliğe ölçü kabul ediliyor. $\mathrm{Bu}$ düşünce sadece terakki manasıyla muteberdir, mazi ile bağı kopmuş terakki de mukaddeslerin yıkılmasından geçer ve elimizde yabancı kültürle yozlaşmış bir nesil kalır. Nitekim Atatürk de bu cümlesini 3 yıl kadar sonra... değiştirmiştir².

İkinci açı: yüz ağartıcı olmayan musiki yayımı. Cumhurbaşkanını kendi ülkesinde kendi musikisini kendi milletvekillerine şikâyet ettiren âmil, bu musikiye aşırı sevgisidir: onu yalnız eğlendiren değil, düşünmeğe, üzülmeğe, çareler aramağa sevkeden tutku. "Amcası, oğlum bir serseri mi olacak acaba?" kabilinden.

Türk makam müziğinin teknik ve tarihî geçmişine ait niteliklerinden ziyade disiplinli ve özenli yaklaşımlardan uzak bir anlayı̧̧ın, "piyasalaşma” "nın hakim olduğu bir icra uslubuna vurgu yapan bu ifadelerini, Neyzen'den yaptığı alıntı ile pekiştirir Tanrıkorur ve konuşmasını şöyle sürdürür (Tanrıkorur 1978: 16):

Aynı laubalilik, aynı Aşk yüzünden Neyzen’i de isyan ettirir;

Tüylerim ürperiyor duydukça

Musiki namına zillet şu sazı

Yurdumuzdan azametle yayilır

Cehlin âfâk-1 cihana avazı

Telsizin işlemesinden maksat

Çıksın üç-beş pezevengin boğazı

Tanrıkorur'un Türk müziğinin temsiliyetinde icra disiplinine dair Neyzen'den verdiği bu örneğe benzer bir serzenişti, Neyzen Tevfik'ten ney dersleri alan Mehmet Akif de Misır Prensesi Emine Abbas Halim'e yazdığı bir mektup-

2 Tanrıkorur'un Musiki Mecmuası'nda yayınlanan bu yazısının, bir toplantı esnasında yaptı̆̆ konuşmadan aktarıldığı anlaşılmaktadır. Zira metnin aralarına düşülen notlar, Tanrıkorur'un kendisine hatırlatma olarak düştüğü ve konuşma sırasında hangi kaynaklardan okumalar yapması gerektiği yönündeki notları içermektedir. Tanrıkorur bu ifadelerinin hemen ardına Atatürküün bu konuda sarfettiği sözleri Muammer Sun'dan alıntı yaparak okumak için M. Sun, 24 notunu düşmüştür. Anlaşılan odur ki Cinuçen Tanrıkorur, konuşmasına bu kaynaktan okuma yaparak devam etmiş ve kendi yorumuna delil olarak bu ifadeleri kullanmıştır.

"Kendi kitabından okuyorum", " s.39'dan okunacak" gibi ifadeler de metin içerisinde sıklıkla görülmektedir. 
ta "...son zamanlarda hanende musikisinden adeta iğrenir oldum..." ifadeleri ile yapar (Arslan 2015: 142). Millî değerlere ve geleneğe samimiyetle bağl1 bu isimlerin, Türk müziğini değil onun temsil ediliş şekline olan eleştirileri, benzer şekilde Cumhuriyet ruhunu temsil edecek bir "yeni musiki" arayışında Atatürk'ün de "yeni" bir musiki vurgusunu anlamaya yardım eder. Cinuçen Tanrıkorur, Ulu Önder'in gerçekleştirmek istediği musiki inkılabını uygulamaya koyanları da son madde olarak verdiği aşağıdaki ifadelerle eleştirir (Tanrikorur 1978: 16).

Üçüncü açı: 'ulusal ince duyguları, düşünceleri anlatan yüksek deyişleri, söyleşileri toplamak, bunları bir gün önce genel son musiki kurallarına göre işlemek gereklr" sözüyle "Halk Türkülerini Armonize Edin” demek istemiş olmasını-hatta Gökalp’in bu sözlerle belirttiği hedefi düzeltmiş olmasına- rağmen, ellerinden "halk türküsü armonize etmek"ten başka bir şey gelmeyen çevresindeki ileri müzikçiler, sözü kendi kabiliyetlerine tercüme ediyorlardi...

$\mathrm{Bu}$ ifadelerde Tanrıkorur'un Atatürk'ün yeni musiki idealini, son yıllarda kaleme alınan metinlerden (Kutluk 2016) daha farklı değerlendirdiği görülmektedir.

Konuşmasını, Cumhuriyet dönemi uygulamalarının O'nun düşüncesini yansıtan hedefler olmadığına dair inancını, ölümünden bir iki sene önce Vasfi Rıza Zobu'ya da anlattığını ifade ederek pekiştirir ${ }^{3}$ (Tanrıkorur 1978: 16).

Tanrıkorur, Atatürkçülük üzerinden yürüyen bu millî musiki tartışmalarında, kendisini "Atatürk’ün müzisyeni” olarak tanımlayan Hikmet Şimşek ile de hararetli tartışmalara girmiştir. Hikmet Şimşek’in, sürekli yazarlarından olduğu Orkestra dergisi üzerinden Tanrıkorur'a "Bay Cinuçen Tanrıkorur'un İki Yazısına Bir Cevap (Şimşek 1997: 7), Ve Bir Mektup” (Şimşek 1997: 21), "Bir Açıklama" (Şimşek 1998: 52) başlıklı yazıları, bu tartışmaların izlerini yansitan yazilardir.

3 Tanrıkorur'un konuşması esnasında banttan dinlettiği anlaşılan bu kaydın içeriğini metinden takip edebilmek mümkün olamasa da bu anlatı çeşitli hatıratlarda aşağıdaki ifadelerle yer bulur.

Ne yazık ki benim sözlerimi yanlış anladılar, şu okunan ne güzel bir eser, ben zevkle dinledim, sizler de öyle. Ama bir Avrupalıya bu eseri, böyle okuyup da bir zevk vermeye imkan var mı? Ben dedim ki bizim seve seve dinlediğimiz Türk bestelerini, onlara da dinletmek çaresi bulunsun, onların tekniği, onların ilmiyle, onların sazları, onların orkestraları ile çaresi her neyse... Biz de Türk musikisini milletlerarası bir sanat haline getirelim dedim. Türk’ün nağmelerini kaldırıp atalım, sadece garp milletlerinin hazırdan musikisini alıp kendimize mal edelim, yalnız onları dinleyelim demedim, yanlış anladılar sözümü. Ortalığı öyle bir velveleye verdiler ki ben de bir daha lafını edemez oldum. (Ataman 1991:20). 
Söylemleriyle ve besteleriyle geleneğe olan bağlılığını her firsatta ortaya koyan Tanrıkorur'un uygulamalarının, gelenekle ilişkisi noktasında bugün makam müziği araştırmacılarının özellikle kuramsal alanda eleştirdiği Arel'in ve Arelcilik'in soyut hedeflerine benzeyen de pek çok yönü bulunmaktadır. Ancak Cinuçen Tanrıkorur'un bu hedeflere ulaşma biçimi, Osmanlı kimlik ve geleneğine sadık bir aydın tipolojisi ile gerçekleşir. Musiki Mecmuası'nda yer bulan "Arelcilik Nedir?" sorusuna cevap olarak verilen her maddenin Tanrıkorur'un yaşam biçimi ve üretimlerinde aktif bir karşıllı̆̆ da vardır.

Arelcilik; millî musiki yani Türk musikisine ilim yoluyla sonsuz aşktır.

Arelcilik; herşeyin üzerinde Türk musikisine hizmet etmektir.

Arelcilik; Türk musikisi hizmetinde durmadan, bıkmadan yorulmadan çalışmaktır.

Arelcilik; Türk musikisine yapilacak hizmeti ilim yoluyla en iyi bir şekilde yapmaya çalışmaktır.

Arelcilik; Türk musikisinin değerini tanıtmak, korumak ve yükseltmek için çalı̧̧maktır.

Arelcilik; eski musikimizin karakterini bozmadan kendi bünyesinden doğan armoni ile çoksesli hale ulaştırmaya çalışmaktır.

Arelcilik; Türk musikisini dünya musikisi haline getirme yolunda çalışmaktır (Üngör 1968 : 13).

Tanrıkorur'un 30'lu yaşlarında Arel'i, medenî olmak için Avrupa'yı merkez alan bir şahsiyet değil, aksine müzik üzerinden Türk kimliğini yükselten bir milliyetçi olarak değerlendirdiği de aşağıdaki şu sözlerden anlaş1lır (Tanrikorur 1968: 9):

Hüseyin Sadettin Arel, medenî olmanın batılı olmak anlam1na gelmediğini; samimi, ciddî ve ilmî düşünmesini bilen her Türk'ün en az bir batılı kadar medenî olabileceğini -perilerin ve insanların diliyle- ilk defa olarak isbat eden bir büyük Türktür.

Ancak y1l 1996'ya geldiğinde Tanrıkorur, Arel'in "Ben Türk musikisinin mazideki tecelliyatına değil, istikbaldeki çoksesli haline meftunum” sözünü kendi kültürünü gizliden gizliye küçümseyen bir Tanzimat aristokratının büyüklük kompleksine benzetir (Tanrıkorur 2001:51). Arel'in, çoksesliliği hedef olarak 
belirleyen hayaline karşılık Cinuçen Tanrıkorur, çokseslilik barındıran bestelerini bir gelişmişlik unsuru olarak değil, ifade etmek istediği duyguya bağl1 teknik bir tercih olarak ortaya koymuştur. Döneminin müzik tartışmalarının TRT üzerindeki yansımalarını ve Tanrıkorur'un bu konudaki eleştirilerini, aşağıda yer verilen ifadelerinde görmek mümkündür (Tanrıkorur 2001: 52)

TRT’nin ünlü şeflerinden birinin yönetiminde periyodik olarak verilen TV konserlerinden birinde, şiiri R. Körüklü'ye ait Hüseyni makamında "Turnalar" isimli bir türküm yayınlanmıştı. Beste öyle yapılmadığı halde, nezaketen görüşümün alınmasına dahi lüzum görülmeden nakarat kısmı çokseslendirilerek icra edildi. Ancak bu Türk kaşığı ile Batı çikolatası yeme hastalığı bir Tanzimat uzantısı Piyano belasını Türk musikisinin başına saran (Uş̧̧ak, Hüzzam, Karcığar fasıllarında bile piyano çaldırmakta mahzur görmeyen) TRT'ye mahsus değil. Kültür Bakanlığı İzmir Devlet Korosu da aslı klasik tarzda olan eserleri, üstelik bestecilerinin gözü önünde çokseslendirerek ... bunu pek büyük bir marifet zannediyor.

Klasik repertuarı ve üslubu temsil ederek yüksek sanat eserlerinin seslendirilmesinde önemli bir sorumluluğu olan TRT ve devlet korolarının dahi "yenilikçilik" heyecanı ile pekçok şeyi göz ardı eden bir çokseslendirme tutkuları olduğunu, Tanrıkorur bu sözlerle ifade etmiştir.

\section{Tanrıkorur Bestelerinde Yenilikçi Unsurlar}

\section{1. Çoksesli Pasajlar}

Makam müziği geleneğine ait olmayan çokseslilik uygulamaları Tanrıkorur'un besteciliğinde, müziğin ifade kuvvetini, ihtiyaç halinde yükselten bir unsur olarak kullanılmıştır. İki ud için bestelediği Acemaşiran Sazsemai, 3 Udun Sohbeti isimli Rast Saz Eseri, iki ud için düzenlediği Mesut Cemil’in Nihavend Sazsemaisi veya zaman zaman sözlü eserlerinin bazı pasajlarında kullandığı çoksesli yapılar bu anlayışına örnektir.

Aşağıdaki tabloda, onun sözlü eserlerinde bulunan çoksesli beste ve pasajlarının örnek bir listesi bulunmaktadır. Bu eserlere tarihsel olarak bakıldığında, bestecinin çoksesli uygulamalarının, 60'lardan itibaren başlayıp 1990 ile 1998 yılları arasında yoğunlaştı̆̆ dikkati çekmektedir ${ }^{4}$.

4 Sözlü eserlere dair çoksesli pasaj ya da bestelerin tespiti, Reha Sağbaş (2018) editörlüğünde, Barihüda Tanrıkorur tarafından yayına hazırlanan "Cinuçen Tanrıkorur Beste Külliyatı" isimli çalışma temel alınarak yapılmıştır. 
Tablo 1. Tanrıkorur'un Çoksesli Unsurlar Barındıran Sözlü Eserleri

\begin{tabular}{|l|l|c|}
\hline Eserin adı & Form/Tür & Beste yzl \\
\hline Yaz Kuşu & Şarkı & 1963 \\
\hline Garip Yıldızlar & Fantezi & 1963 \\
\hline Güneş mi Güzel Yüzün mü? & İki ud için beste & 1969 \\
\hline Kar musikileri & Fantezi & 1990 \\
\hline Mavi Geceler & Fantezi & 1990 \\
\hline Itrî & Destan & 1990 \\
\hline Malazgirtîn İlk Işıkları & Destan & 1990 \\
\hline Nur Gerek & Dini konulu beste & 1990 \\
\hline Vatan Destanı & Gençlik Şarkısı & 1991 \\
\hline Cemil Ölürken & Mersiye & 1991 \\
\hline Büyük Ata'ya & Ağıt & 1991 \\
\hline Mehlika Sultan & Fantezi & 1991 \\
\hline Mahzun Şehir & Ağıt & 1992 \\
\hline Sularda Akşam & Fantezi & 1992 \\
\hline Kız Kulesi & Fantezi & 1993 \\
\hline Bir Eski Şarap Lezzeti & Şarkı & 1970 \\
\hline Akşam Musikisi & Fantezi & 1995 \\
\hline Yedi Cüceler & Sazsemaisi & 1995 \\
\hline Mohaç Türküsü & Destan & 1995 \\
\hline Mevsimler & Fantezi & 1995 \\
\hline Köylü Kızıma & Türkü & 1991 \\
\hline Aşk Düşlerde & Fantezi & 1996 \\
\hline Köy Camii & Fantezi & 1998 \\
\hline Suç Kimin & Fantezi & 1992 \\
\hline & & \\
\hline & & 1990 \\
\hline
\end{tabular}

Bu liste dışında da bestecinin Avrupa sazlarını da dahil ettiği ve çoksesli unsurlar da içeren pek çok düzenleme ya da bestesi bulunmaktadır. 1969'da Necati Gençsoy'a ithafen Ud, Kanun, Çello ve Obua için bestelediği eseri, yine konser parçası olarak Hüseyni-B Minör notuyla ud, flüt ve çello için yazdığı Anatolian Fields isimli Hüseyni saz semaisi çeşitlemesi, bu yaklaşımına birer örnektir. Bu örneklerden başka, saz eseri besteciliğinde kullandığ çoksesli beste ve pasajların tamamını içeren eserleri ise aşağıdaki tabloda verilmiştir. 
Tablo 2. Tanrıkorur'un Çoksesli Unsurlar Barındıran Saz Eserleri

\begin{tabular}{|l|l|c|l|}
\hline Tür & Makam & Beste Y1lı & Çoksesli Yapı \\
\hline Sazsemaisi & Acemaşiran & 1959 & 4. hane \\
\hline Sazeseri & Yeni Çargah & 1969 & İki ud için \\
\hline Sazsemaisi & Hüseyni & 1971 & Flüt, ud, çello için \\
\hline Sazsemaisi & Nihavend & 1985 & İki ud için \\
\hline Sazsemaisi & Acemaşiran & 1985 & Flüt ve ud için \\
\hline Sazeseri & Rast & 1986 & 3 ud için \\
\hline Medhal & Mahur & 1988 & 1. hane \\
\hline Konser Parçası & Evcara & 1990 & 1. hane \\
\hline Medhal & Şehnaz & 1990 & Piyano için \\
\hline Sazeseri & Hicazkar & 1991 & 4. hane \\
\hline Medhal & Buselik & 1993 & Teslim \\
\hline Sazsemaisi & Acemaşiran & 1995 & İki ud için \\
\hline Sazsemaisi & Buselik & 1995 & 1., 2. ve 3. haneler \\
\hline Oyun Havası & Şehnaz & 1997 & Taksim bölümleri \\
\hline Medhal & Nihavend & 1997 & 3. hane \\
\hline Sazeseri & Nişaburek & 1998 & 3. hane \\
\hline Cenaze Marş1 & Dügah & 1999 & Tamamı \\
\hline
\end{tabular}

Kullandiğı Edebi Formlar Üzerinde Yaptı̆̆ı Bestelerindeki Çoksesli Yapılar ve İlgili Açıklama Notları

Tanrıkorur'un yukardaki eserlerde kullandığı çoksesli pasajlar, çeşitli edebiyat formları aracılığ 1 ile ortaya koyduğu bestelerinde de bulunmaktadır. Mersiye, Destan ve şiir tercihlerinde, Türk kültür tarihini konu edinen ve sanat değeri çok yüksek olan güfteler onun karakteristik tercihlerinden biri olarak dikkati çeker. Bu yolla ürettiği eserlerde recitatif duyum, söz ile müzik arasında ilişki kuran ritmik ve makamsal yapı, atlamalı aralıkların kullanımı ya da belirli pasajlardaki çoksesli unsurlar, Tanrıkorur yenilikçiliğinin öne çıkan unsurları haline gelir. O’nun bu eserler üzerindeki yenilikçi uygulamaları, sadece nağme üretimi alanıyla sınırlı değildir. Notalar üzerinde kullandığı nüans işaretleri ve aktarılmak istenen duyguyu ifade eden açıklama notları, künyelemedeki titizliği gibi her form üzerinde görülen konular, bu eserlerde de dikkat çekici unsurlardandır. 
Bahsedilen bu türlere farklı formlardan birkaç örneği aşağıda görmek mümkündür.

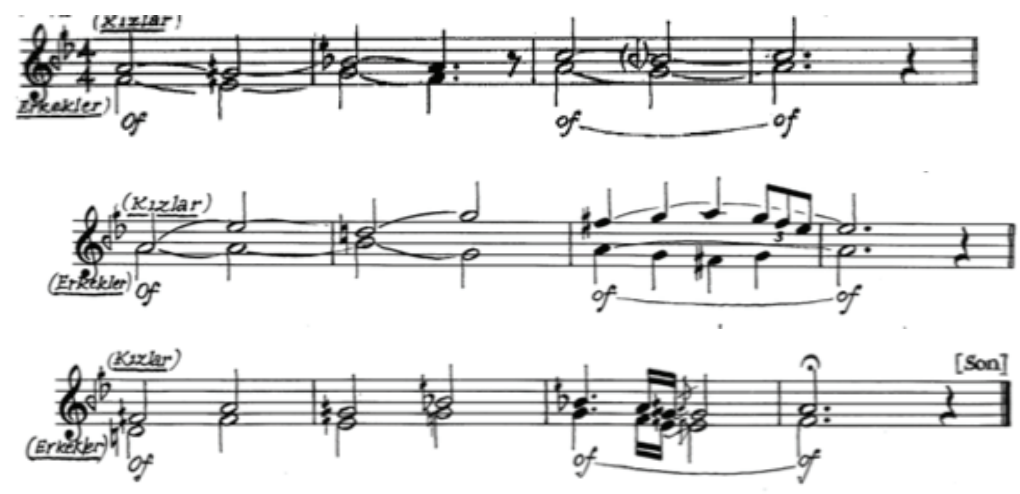

\section{Örnek 1. Dügâh Ağgt, Büyük Ata'ya}

Faruk Nafiz Çamlıbel'in şiiri üzerine, Dügah makamında bestelenen bir ağıt olan bu eserde bestecinin giriş, orta ve son bölümlerde yer alan "of" terennümlerini, kadın ve erkek seslerine ait partiler ile planladığ 1 ve bu yolla üçlü, altılı ve oktav aralıklarını duyurmayı istediği görülmektedir. Güftenin girdiği bölümler ise geleneksel yapıda bestelenmiştir.

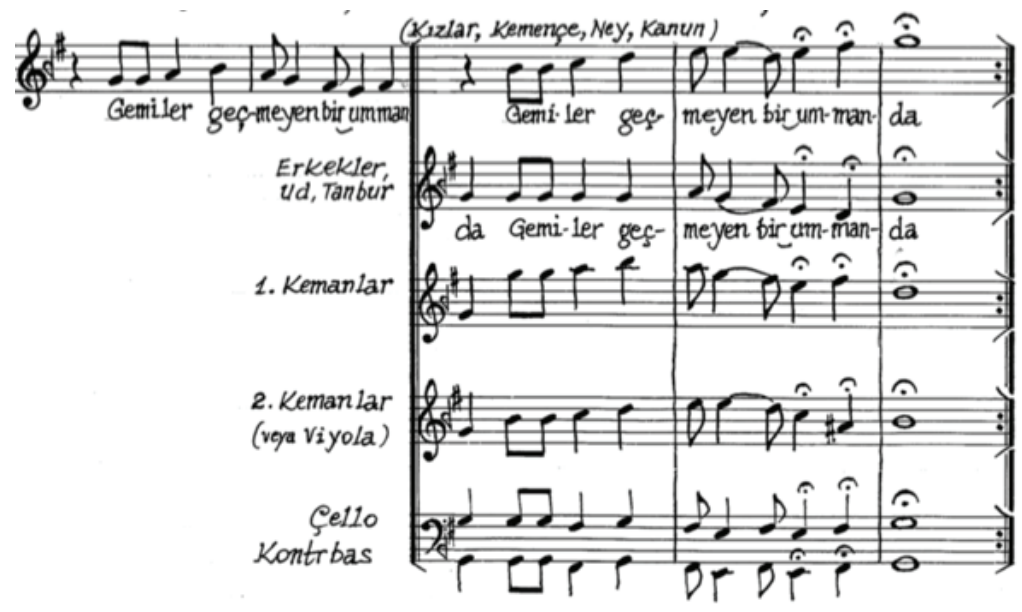

\section{Örnek 2. Itrî, Rast Destan}

Edebî bir anlatı olan destan türü üzerine bestelediği yukarıdaki örnekte de bestecinin sadece erkek ve kızlara ait ses partilerini değil enstrumanlar partilerini de belirleyerek eserin bitiş etkisini bu çoksesli duyuş ile desteklemek arzusunda olduğu anlaşılmaktadır. 
Aşağıdaki örnek ise Kürdilihicazkar makamında bir mersiyedir. Tanrıkorur, eserin icrasına yönelik her detayı hem nota üzerinde hem de eserin sonuna not düşerek yaptığ 1 açıklama ile göstermiştir. Bu tip açıklamalar ve icraya yönelik her tür detayın nota üzerindeki gösterimi, onun yenilikçi ve yüksek disiplin sahibi kimliğinin bir yansımasıdır. Zira makam müziğinde nota yazımına dair alışkanlıklar, Cinuçen Tanrıkorur'un bu titizliğinden oldukça uzaktır. Bestelediği eserleri kendi el yazısı ile yazmış olmasına ve müziği ifade edecek her tür unsuru nota üzerinde göstermesine ilave olarak, eserlerinin beste numarası ve bestelendiği yer bilgilerini de bu yazımlara dahil etmesi, onun titizliğinin yanısıra Türk makam müziğinin aldığı eleştirilerin musikinin kendisinden değil onu temsil eden zihniyetlerden kaynaklanmı̧̧ olduğunu da somutlaştırmış olur. Bu detayda bir künyeleme Türk makam müziği bestecilerinde pek te görülmeyen bir uygulamadır.

Tanrıkorur'un, bu musikinin geçmişteki ve kendi dönemindeki önemli besteci ve icracıları için de yazmış olduğu pek çok eseri bulunmaktadır. Örnek 2'deki bestesi onun aynı zamanda bu kategoride de değerlendirilebilecek eserlerinden sadece bir tanesidir. Itrî ve Mesut Cemil Bey gibi önemli isimler için bestelemiş olduğu bu eserlerdeki bazı pasajlarda, bestecinin yine çoksesli tınıları dahil ederek bestelediği görülür.

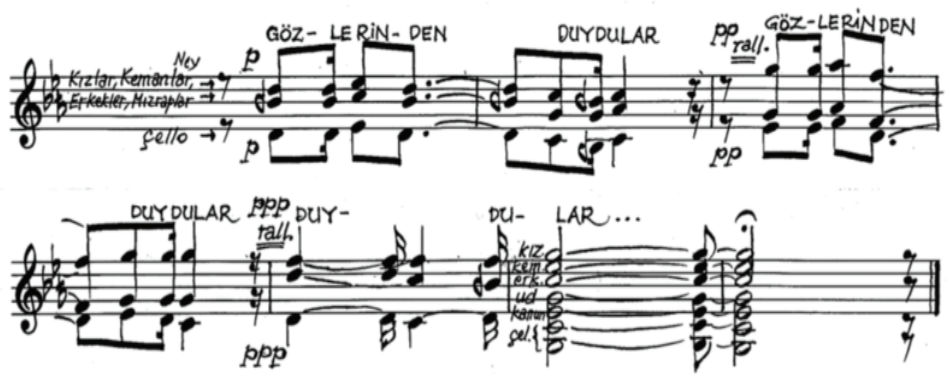
Not: Parca, mersiye formunun gerektirdiğ yumusak ve hüzülü üslopisinde ic a edilecektir (akine isaret yoksa). usûlü prozodik itinaile kullanilisy, amaçantan yar1-resitatif havayz kolaylastiracaktir.

\section{Örnek 3. Kürdilihicazkâr Mersiye, Cemil Ölürken}

Mesut Cemil için bestelediği bu eser için Tanrıkorur, divan edebiyatının köklü bir nazım türü olan mersiyeyi tercih etmiştir. Mersiyeler, ölen kişinin güzel yönlerinin, kahramanlıklarının, hizmetlerinin övüldüğü ve ölümün- 
den duyulan acının ifade edildiği türlerdir. Bu duyguları ifade etmek için Tanrıkorur'un bestesine düştüğü nota yansıyan yarı resitatif hava, tecvit geleneğine dayanan bir okuyuş biçimidir. Sözün ya da mesajın duyurulmasının müziğin ardında kalamayağ 1 türler için bestecinin bu resitatif duyum yaratacak tartımları, prozodiyi öne çıkaracak şekilde kullandığı görülmektedir. Yukarıdaki mersiye de Nazım Hikmet'e aittir ve şiirin böyle büyük bir şaire ait olması, Tanrıkorur'un resitatif duyum yaratarak şiiri öne çıkarmayı tercih etmesinin önemli sebeplerinden biri olması çok muhtemeldir. Edebi türler üzerine yaptığ 1 besteler ya da bazı fantezilerinde de bu duyumun amaçlandığ1 görülür. Mersiye gibi geleneksel ve manevi unsurlarla örülü bir tütün içinde kullandığı çoksesli pasaj da onun gelenek ve yenilik arasındaki konumunu ifade etmeye güzel bir örnektir.

Beşyüzbeş eser arasından seçilen bu birkaç eser, Cinuçen Tanrıkorur'un bestelerinin, Cumhuriyet döneminin yeni müzik arayı̧ıındaki söylemlere ve yenileşme hamlelerine cevap veren vasıflarını temsil etmektedir.

Bu dönemin resmi söylemlerinden biri olan Türk kültürü ve kimliğinin yansıtılmasını sağlayacak "yüksek deyişler"in öne çıkarılması ve bestelenmesi hedefi, Tanrıkorur'un bestecilik alanı içinde sıklıkla yer bulan ve yepyeni bir tasarımla makam müziği dünyasına dahil olan üretimlerindendir. Bu üretimlere karşıllk olarak gösterilebilecek olan bestelerinde sözlerin atasözleri, destanlar, şiirler gibi edebî türlerden ve Kur'an lafızları gibi manevî unsurlardan seçilmiş olduğu görülmektedir. Bu türlere ait sözlerin güfte amacıyla kullanılması ve buna bağlı olarak çok çeşitli türlerde ve bu tercihe bağlı olarak tasviri olarak da ortaya çıkabilen besteleriyle, Tanrıkorur diğer bestekarlardan ayrı bir yerde durmaktadır. Dikkat çekici bir tercihle yöneldiği görülen şiir besteciliği, gerek kendi döneminde gerekse günümüzde makam müziği bestecilerinin anlatımlarında fazlaca yer bulmaz. Böylesi tercihlerde bulunan bestecilerin, edebiyat ve musiki ilişkisine/ birlikteliğine önem veren entelektüel yapıda sanat insanları olduğu görülür. Münir Nurettin Selçuk da bu tercihle beste yapan sanat adamlarından biridir. Yahya Kemal Beyatlı'nın şiirleri üzerine yaptığı bestelerle tanınan Münir Nurettin’in bu bağlamda hemen ardından gelen ilk isimdir Cinuçen Tanrıkorur. Gerek Yahya Kemal şiirleri gerekse de diğer aruz şairlerinin ve belirli hece vezni şairlerinin eserleri üzerine çok sayıda beste yapmıştır. Hatta bazı şiirleri öylesine sevmiştir ki aynı şiir üzerine farklı makamlardan birkaç beste yaptığı görülür. Aşağıda sözleri verilen Besim Berkmen'e ait olan şiir, bahsedilen bu durumun tipik bir örneğidir. Bu güfte Kürdilihicazkar, Hicaz, Rast ve Uşşak olmak üzere dört farklı makamdan ve şarkı formunda bestelenmiştir. 
Beni bûyün ile gel mest ü rehavi ediver Hastanım, göğsünün üstünde tedavi ediver Nazarımda günü berrak göğü mavi ediver Hastanım, göğsünün üstünde tedavi ediver

Yine benzer bir örnek, Faruk Nafiz Çamlıbel'in destan formundaki şiiridir. "Enginlere at sürdüğün akşamdı kenardan" mısrasıyla başlayan bu destanı Tanrıkorur, Mahur ve Buselik makamlarında bestelemiştir. Neyzen Tevfik Kolaylı'nın "Iztırabın sonu yok sanma bu alem de geçer" mısrasıyla başlayan şiiri de Tanrıkorur'un bu tercihinin örneklerindendir. Bu güfteler de, Hicaz ve Buselik makamlarında şarkı formunda bestelenmiştir ve bu örneklerin sayısını artırmak da mümkündür.

\section{Saz Eserlerinde Kullandığı Çoksesli Yapılar}

Saz eserlerindeki çokseslilik uygulamalarına verilecek örnekler içinde ilk sıralarda dikkati çekecek olan sazeseri, bestecinin Acemaşiran sazsemaisidir. Bu sazsemaisine Tanrıkorur, farklı vesilelerle üç çeşitleme yazmıştır. Eserin orijinal hali geleneksel ve tek sesli bir beste olmakla birlikte Sağbaş'in editörlüğünde hazırlanan külliyata göre bu beste üzerindeki çeşitlemeler Bağdat konservatuarındaki meslektaşlarının ve bir öğrencisinin talep ve ihtiyaçları doğrultusunda düzenlenmiştir. Aşağıda verilen örnek flüt ve ud için yaptığı çeşitleme üzerinedir.

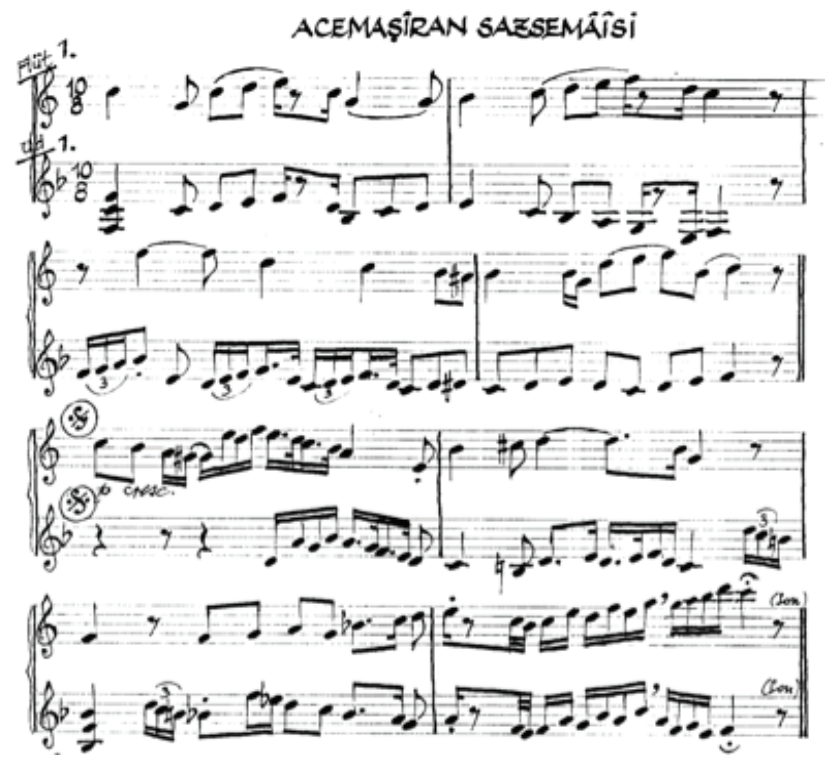

Örnek 4. Acemaşiran Sazsemaisi / Flüt ve Ud İçin 


\subsection{Geniş Atlamalı Aralık ve Arpej Kullanımı}

Tanrıkorur bestelerinde dikkat çeken unsurların birisi de makam müziğinde alışlagelmiş bir kullanım şekli olan, seslerin yanyana diziliminden oluşan nağmeler tasarlamak yerine geniş atlamalı aralıkların eserlerinde sıklıkla yer bulmasıdır. Saz eserlerinde görüldüğü kadar sözlü eserlerinde de görülen bu yapı, bestecinin işlediği makamın rengini ortaya koymasına engel olmayan bir orijinallik taşımakta ve aynı zamanda bestecinin kimliğini de ortaya koyan bir üsluba dönüşmektedir. Ud metodunda bulunan "3 Cambazın Gösterisi” isimli üç etüdü, tümüyle arpej ve akor kalıplarından oluşan melodiler üzerine bestelenmiştir. Aşağıda verilen 'Su Samurunun Aşkı" isimli Buselik Sazsemaisi ise Tanrıkorur'un melodi kurgusunda sıklıkla tercih ettiği geniş atlamalı aralık kullanımlarına bir örnektir.
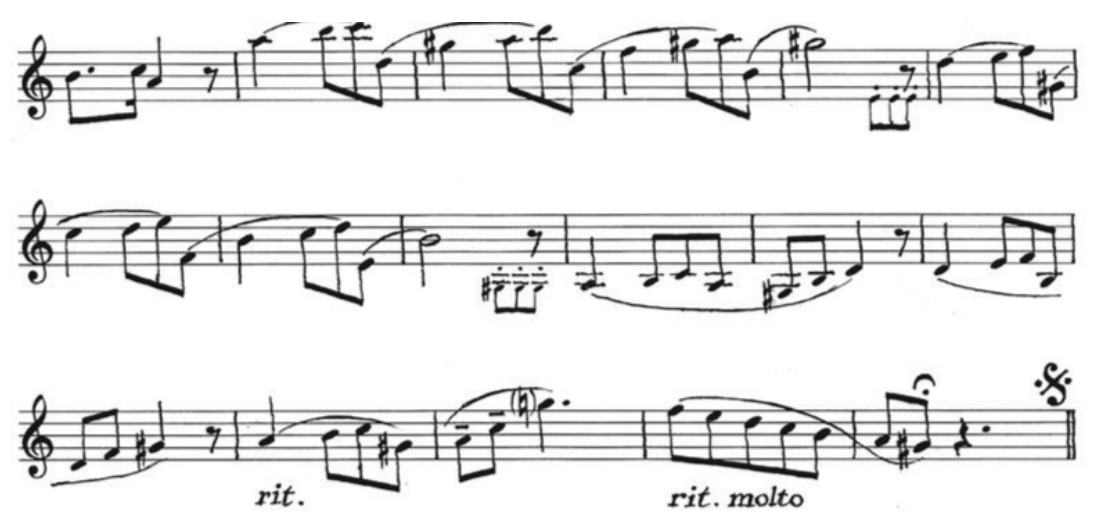

\section{Örnek 5. Su Samurunun Aşkı}

\subsection{Nota yazısındaki Yenilikçi Uygumaları}

Tanrıkorur'un yenilikçi uygulamaları sadece bestecilik ve icra alanı ile sınırlı olmayıp nota yazımını da içine almaktadır. Bestelediği eserlerin tarih, yer ve numara bilgilerini özgün ve titiz el yazısı ile yazdığı notalar üzerinde künyelemesinin yanısıra vurmalı çalgılar için Avrupa nota yazım sisteminin kullandığ̣ işaretlemeleri kullanması, Türk makam müziği nota yazımına dahil ettiği yenilikler arasındadır. Aşağıda verilen örnekler de bestecinin 1979 yılında Ankara'da bestelediği 'Bekçi Baba" isimli çocuk şarkısı ile "Güzeldendir, Güzeldendir" isimli Uş̧̧ak bestesinin davul ve bendir partilerine aittir. Makam müziğinde davul ve bendir sazlarının ayrıca notalanması, alı̧̧ılagelmiş bir uygulama olmayıp Tanrıkorur'un müzikal duyum ve yazım hassasiyetinin temsillerinden bir tanesidir. 


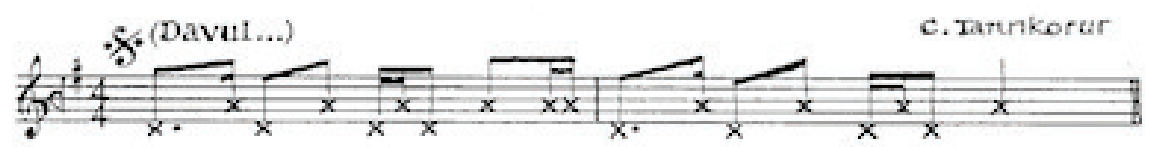

\section{Örnek 6. Bekçi Baba}

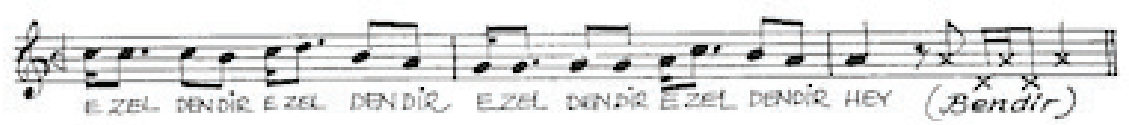

\section{Örnek 7. Güzeldendir, Güzeldendir}

Tanrıkorur'un notalamaya dair geleneksel uygulamalardan bir başka farklı uygulaması, icra sırasında doğal olarak doğaçlama kullanılan varyasyonlar üzerinedir. Türk müziği icracılarının icra esnasındaki tercihleriyle şekillenen bu yorumlama tekniğini Tanrıkorur, 19 yaşındayken standartlaştırmayı denemiş ve Nişaburek Sazsemaisi'nin mülazimesinin ilk ölçüsünü varyasyonlu olarak da yazmıştır.

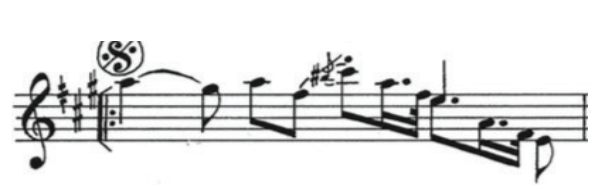

Mülâzime ilk ölçü varyasyonu:

\section{Örnek 8. Nişaburek Sazsemaisi, 1957, beste no.9}

Bu örnek, bir yandan Tanrıkorur'un Türk makam müziğinin her icrada yeniden yaratılabilen doğasını hedef alan eleştirilere, her detayı yazıya dökerek çok daha sistematik bir notalama ortaya koyma cevabı olarak yorumlanabilir. Diğer yandan icra esnasında yapılacak her tür süsleme ve ifadeyi titizlikle belirtme isteğinin bir başka örneği olarak da görülebilir. Çok erken yaşlarından itibaren bestecinin nota yazımında görülen bu yaklaşım, Avrupa notalamasındaki standardı ve kuralcılığı Türk müziğine kazandırma amacının yansımalarıdır.

\section{Mevcut Ses Sistemine Bağlı Notalamayı Onarma Çabaları}

Nota yazımında klasik gelenekten farklı olarak kullandığı diğer bir örnek ise aşağıda bir kısmı verilen "Su Samurunun Aşkı" isimli saz eserinde görülür. Bu eserde Tanrıkorur, değiştirici işaretleri donanıma yerleştirirken, halk müziği 
nota yazımında kullanılan şekle benzer biçimde rakamlayarak göstermiş ve eserin sonuna "Rakamlar, kullanılan arızanın koma sayısını gösterir" notunu düşmüştür. Bu deneme, Arel sisteminin bazı perdeleri ifade etmedeki yetersizliğine, bestecinin geliştirdiği bir çözüm arayışı olarak yorumlanabilir.

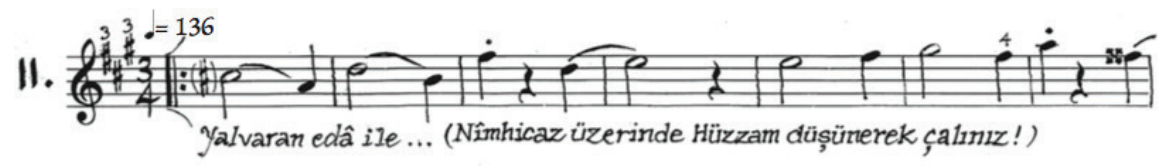

\section{Örnek 9. Su Samurunun Aşkı}

Benzer bir yönlendirme bazı eserlerinde hane başlarına düştüğü notlarla kendini gösterir. Muhayyersünbüle sazsemaisinin 3. Hanesi üzerine düştüğü "saba gibi" notu da bestecinin geleneksel perde sistemini koruma hassasiyetinin bir yansımasıdır.
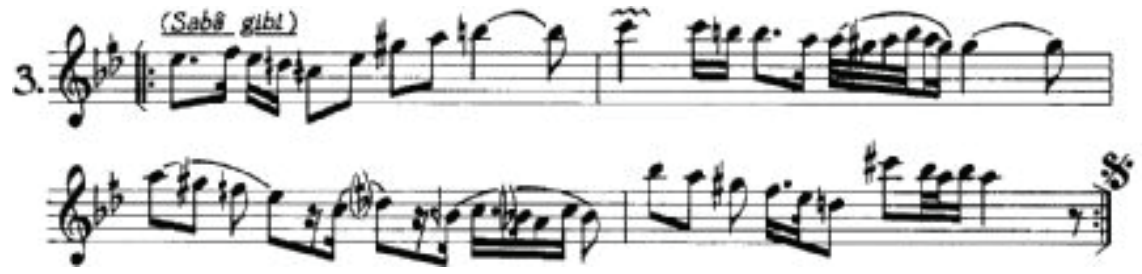

\section{Örnek 10. Muhayyersünbüle Sazsemaisi}

Makamı duyurabilmek için gerekli tüm tedbirleri nota yazımı aracılığıyla da desteklemeyi hedeflediği bu tür denemelerine ilave olarak, icra sırasında tasvir edilecek duyguları, notaların altına düştüğü ifade notları ile de pekiştirmiştir. Ayrıca bu eser, Avrupa müziğinde bulunan konçerto, sonat gibi uzun soluklu eserlerin Türk makam müziğinde de bulunması ve bu yolla saz müziğinin geliştirilmesi yönünde, Tanrıkorur'un attığı ilk adımlardandır (Gülçin Yahya Kaçar, Kişisel Görüşme, 23 Kasım 2018, Alanya). ${ }^{5}$

\section{Kullandığı Yeni Türler}

Bestecinin yenilikçiliğini temsil eden diğer bir unsur, kullandığı yeni türlerdir. Ağıllıkla Türk toplumunun manevi değerleri, inanç dünyası, halk kültürü

Tanrıkorur'un ud öğrencilerinden olan Gülçin Yahya Kaçar, Üniversite yıllarında hocasına, icra uzunluğu ve güçlüğü bakımından Avrupa müziğinin konçertoları, sonatları gibi eserlere olan ihtiyacını dile getirmiş ve aynı yıllarda Avrupa sazlarıyla eğitim alan arkadaşlarının, "sizin eserleriniz iki sayfada bitiyor" eleştirilerine ne kadar üzüldüğünü ifade etmiştir. Yahya'nın anlatısına göre "Su Samurunun Aşkı" isimli eserini Tanrıkorur, bu diyalogdan kısa bir süre sonra bestelemiştir. 
gibi konulardan beslenen besteleri, Tanrıkorur'a özgü üretim alanları içinde yer alır. Besmele, Çocuk Besmelesi, Namaz Bilmecesi, Destan ("hicret" konulu) gibi eserleri sıradışı bir tercihle, bu toplumun inanç dünyasını musiki ile ifade eder ve hem çocukları hem yetişkinleri sanat yoluyla eğitmeyi amaçlayan vasıflar taşır.

Seyr-i natık, sözsüz romans, medhalçe gibi eserleri ve fantezi türündeki sazeserleri ile besteci saz müziğinin etkinlik alanını genişletir. Tanrıkorur tarafından icad edilen seyr-i nâtık ise elli makamı bestesel seyirlerle aktaran, eğitim amacıyla icad edilmiş bir formdur (Harmancı, 2011).

Tanrıkorur'un besteciliğinin dikat çekici özelliğinden bir tanesi de tasviri olarak bestelediği sazeserleridir. Yağız Küheylan, Tarla Dönüşü, Yıldızlı Yaz Akşamları, Mehtapta Yakamozlar, Gül Bahçesi, Su Samurunun Aşkı isimli eserleri, bu yöndeki üretimlerinden sadece birkaçıdır.

\section{Bir Örnek Eser: Kız Kulesi}

Tanrıkorur'un müzik kimliğini temsil eden en güzel örneklerden birisi olan bu eser, güfte-beste ilişkisindeki inceliklerin yanında, aynı zamanda bestecinin Türk müziği Batı müziği kutuplaşmasına cevap niteliği taşıyabilecek pekçok çalı̧masından bir tanesidir. Yukarıdaki bölümlerde ele alınan Tanrıkorur'un müzikte yenilenme anlayışının temsilleri arasında bulunan çoksesli pasajlar ve bu pasajları yer yer müzikteki ifadeyi güçlendirme yolu olarak kullanması, kişisel üslubunun bir parçası olan (Özdemir, Levendoğlu....) geniş atlamalı aralıklar ve üçlü aralıklarla oluşturulan nağme yapıları, nota yazımında gösterdiği titizliğe bağlı olarak eseri künyelemesinin ardından kadın ve erkek sesleri arasındaki pasaj paylaşımlarını, aktarmayı amaçladığı müzikal etkiyi yaratacak nüanslara dair aç1klamaları bu eser içerisinde de rahatlıkla izlenebilmektedir. Müzikal ifade unsurlarının yanında bestecinin şiirin gücünden yararlanan ve şiirin mesajını öne çıkaran tartımları resitatif duyum yaratacak şekilde kullanımı da bu eser de görülebilmektedir.

\subsection{Güfteye Dair}

Şiir 8'li hece vezni ile yazılmış büyük oranda 5+3 kalıbının kullanıldı̆̆ yapıda olup altı kıtadan oluşmaktadır. Besteci, şiirin tüm kıtalarını eserinde kullanmıştır. Şiire konu olan Kız Kulesi, Asya ile Avrupa’yı bağlayan tarihi bir yapıdır ve bestenin işleniş biçiminde de bu kesişimin izleri bulunmaktadır. Tanrıkorur'un bestesine seçtiği bu şiir, 7 kule zindanları ve Battal Gazi gibi Türk tarihinin önemli yapı ve kimliklerine de atıfta bulunmaktadır. 


\subsection{Makam Analizi}

Buselik makamında bestelenen eserin analizine geçmeden önce, makamın geleneksel kuram kitaplarındaki tarifine ve eser örneklerine bakıldığında Çargah ve Hüseyni perdelerinin makamın merkez perdeleri olduğu ve karar hareketinin Zirgüle perdesi ile gerçekleştiği görülmektedir (Hatipoğlu, 2019: 246). Arel nazariyesinde anlatılan Buselik makamı ise tonaliteye daha yakındır ve Buselik beşlisi ile Hicaz dörtlüsünden oluşur (Kutluğ,2000:154). Bu haliyle makam, minör bir dizi görünümündedir ve son dönem eserlerde bu minörleşmiş Buselik makam yapısı daha sık görünür hale gelmiştir. Geleneksel makam yapısında görülen Hüseyni’de Uş̧̧aklı yapılar, Rast ile Çargah arasındaki atlayışa bağlı olan Huzi yapısı, son yüzyılın eser üretimlerinde adeta kaybolmaya yüz tutmuştur. Tanrıkorur'un yenilikçiliğini temsil eden eserlerden biri olan bu bestenin değerlendirilmesinde, geleneksel Buselik makam yapısı ile ilişkisi ve geçki yapılan diğer makamlar çözümlenecek ve analizlerde aşağıdaki kriterler dikkate alınacaktır.

Makam analizi yapılırken aşağıdaki unsurlar dikkate alınmıştır:

- makamin ses sahası

- yapılan geçkiler dahil olmak üzere tüm perdelerin kullanım sıklıkları ve ağırlikları

- merkez ve uydu perdeler arası hareket ilişkileri

- geçki yapılan diğer makamlar

- güfte ve makam ilişkisi

Analizlerde Ertuğrul Bayraktarkatal ve Okan Murat Öztürk tarafından yayınlanan "Ezgisel Kodların Belirlediği Bir Sistem Olarak Makam Kavramı: Hüseyni Makamının İncelenmesi” isimli makalede ortaya konulan ezgi çekirdeği temelli makam analiz modeli "Bayraktarkatal, Öztürk (2012) ve Cenk Güray'in (2012) "Bin Yllın Mirası-Makamı Var Eden Döngü Edvar Geleneği" isimli kitabında açıklanan "sadeleştirme tekniği”" temel alınmıştır. Eserde kullanılan ses sahas1 acemaşiran ve tiz acem arasındadır. Bu yayınlara ilave olarak yine Cenk Güray'ın Horasan'dan Keskine Bir Çı̆̆glk: Muharrem Ertaş- Kırat Bozlağı'nın Çok Katmanlı Analizi Üzerinden Orta Asyảdan Anadolu’ya Aşıklık Geleneğinin İzini Sürmek (Güray, Karadeniz 2019) isimli makalesinden yararlanılmıştır.

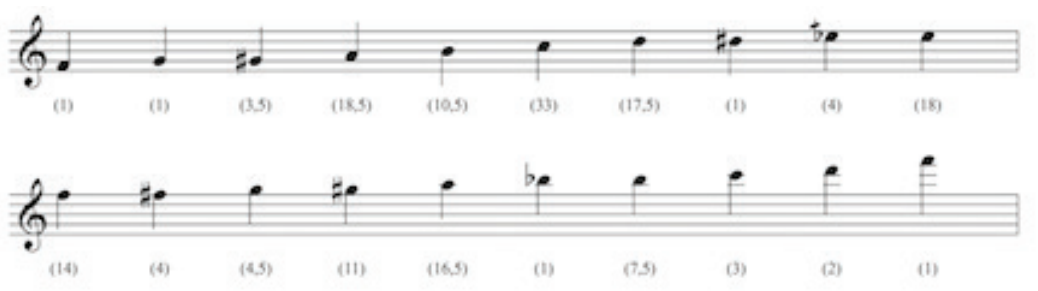


Eserde kullanılan perdelerin ağırlık durumu ise aşağıdaki gibidir.

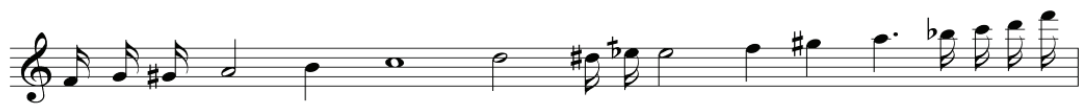

\section{Saz Payı 1}

Eserin başlangıcı, aşağıda görüldüğü gibi rast ve çargah atlayışı ile başlayan tamamı onaltılık birimlerden oluşmuş üçlü aralıklarla ve Buselik makamı perdelerinden oluşan ezgi çekirdekleriyle bestelenmiştir.

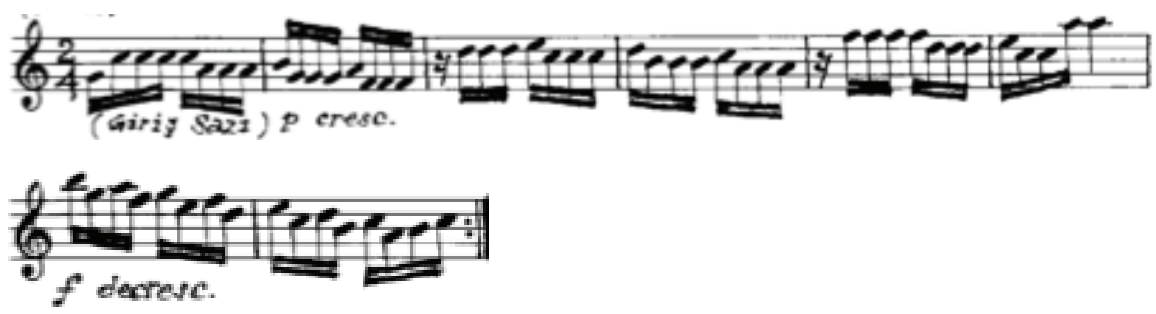

Örnek11. Kız Kulesi Girişi, Üçlü Aralık Hakimiyetiyle Tasarlanan Saz Payı 1

\section{Kıta - Başlangı̧̣ (Karar Bölgesi)}

Eserin başlangıcı olan bu bölümde ezgisel hareket, Buselik makamının geleneksel yapısına uygun bir başlangıç olan rast-çargah atlayışı ile başlamıştır. Huzi çekirdeği olarak da değerlendirilebilecek olan bu başlangıç hareketi, Buselik makamının karakteristik ezgisel hareket tiplerinden biridir ve mana olarak kuvvetli bir kelime olan Güneş kelimesinin heceleri bu atlayış ile bestelenmiştir. İkinci ve dördüncü mısranın son kelimeleri olan 'geçer' kelimelerinin bestelenişinin de eserin başlangıç ölçüsündeki melodik harekete gönderme yapar şekilde kurgulandığ 1 dikkat çekmektedir. Devam eden mısralarda Buselik makamının ezgi çekirdeklerinin kullanımı devam etmiş ve karara gidiş yine çargah perdesinden aşağıya inerek gerçekleştirilmiştir. Eserin ilk kıtası tamamıla Buselik çekirdekleri ile bestelenmiş, farklı bir yapı kullanılmamıştır. 
1. misra

5

Güneş gerdanlık boynunda

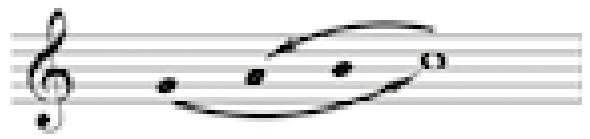

Buselik çekirdeği

3. misra

5

Bir mercan güldür koynunda

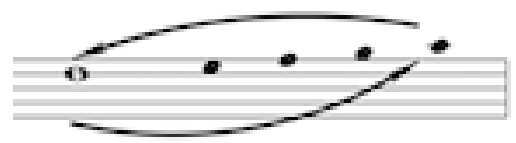

Neva'da Buselik çekirdeği 2.misra

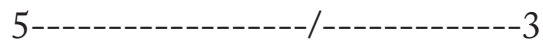

Güneş burcundan al geçer

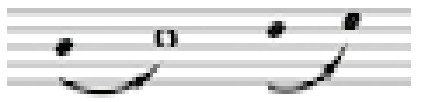

Buselik çekirdeği

4.misra

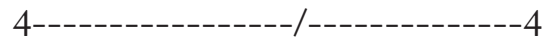

Zaman hayal hayal geçer

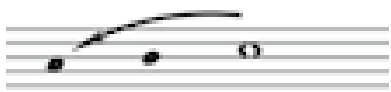

Buselik çekirdeği

\section{Saz Payı 2}

Orta bölgeye giriş niteliği taşıyan saz payı, hüseyni perdesinden başlayan ve yine üçlü aralıklarla acemaşiran perdesine inip buradan oktava atlayarak yine üçlü aralıklarla nim zirgüleye kadar inmiştir. Son cümle olarak ise muhayyer perdesiyle hareket edip dügaha doğru tiz perdelerden bir iniş gerçekleştirmiştir.
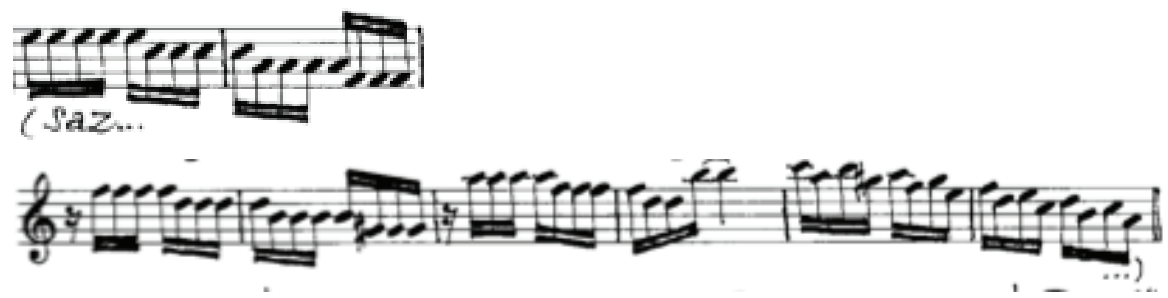

Örnek 12. Kız Kulesi, Üçlü Aralık Hakimiyetiyle Tasarlanan Saz Payı 2 


\section{Kıta-Gelişme 1 (Tiz Bölge)}

Gelişme bölümü, bu ara sazın ardından ikinci kıta ile başlamış olup yine $\mathrm{Bu}-$ selik ezgi çekirdeklerinin görüldüğü bir Buselik makam yapısı içinde bestelenmiştir. Makamın merkez perdelerinden olan hüseyni ile başlayan ezgi, acem perdesinde kalış yapmıştır. Buselik makamının güçlü perdelerinden çargaha karşlık gelen acem perdesindeki bu kalışın ardından, üçlü bir atlayış ile ikinci mısra başlamıştır. Bu üçlü aralık atlayışları eserin tümüne hakim durumdadır. Buselik çekirdeğinin şehnaz ve muhayyer perdeleriyle devam ettiği ikinci mısranın son hecesinde, şehnaz perdesi gerdaniyeye dönüşmüş ve ezgisel hareket yine Buselik çekirdeği ile sürmüştür. Bu kıta da birinci kıta gibi tamamen Buselik makamı ile bestelenmiştir. Her kelime için seçilen tartım yapısı, prozodik yönden eseri yarı resitatif bir yapıya dönüştürmektedir. Bestecinin tercih ettiği bu yapı da eserin tamamında görülmektedir.

1. misra

5

Yosma suların köpüğü

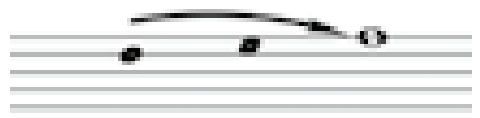

Neva'da Buselik çekirdeği

3.misra

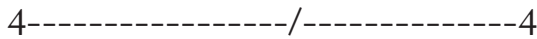

Semâ rengin döküldüğü

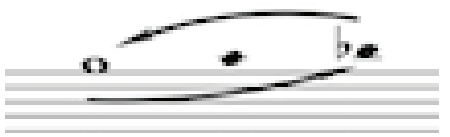

Gerdaniye'de Buselik çekirdeği 2.misra

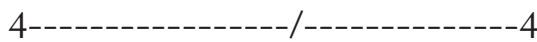

Gözü sarar büyü büyü

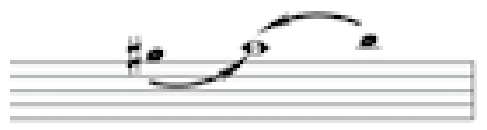

Buselik çekirdeği (Oktav bölgesi)

4.misra

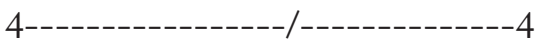

Suda sandal sandal geçer

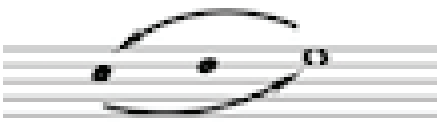

Hüseyni çekirdeği 


\section{Saz Payı 3}

Buradaki saz payı Araban'lı olarak bestelenmiş ve sonraki bölümlerde sıklıkla kullanılacak olan nevadaki Hicaz'ı kullanımların ya da Buselik-Hüseyni ilişkisi bağlamından kaynaklanan Karcığar yapısının hazırlayıcısı olmuştur. Saz payının son ölçüsünde Buselik makamına yapılan dönülmüştür. Diğer saz paylarında olduğu ezginin tasarımının üçlü aralıklar üzerinden kurgulandığı görülmektedir.

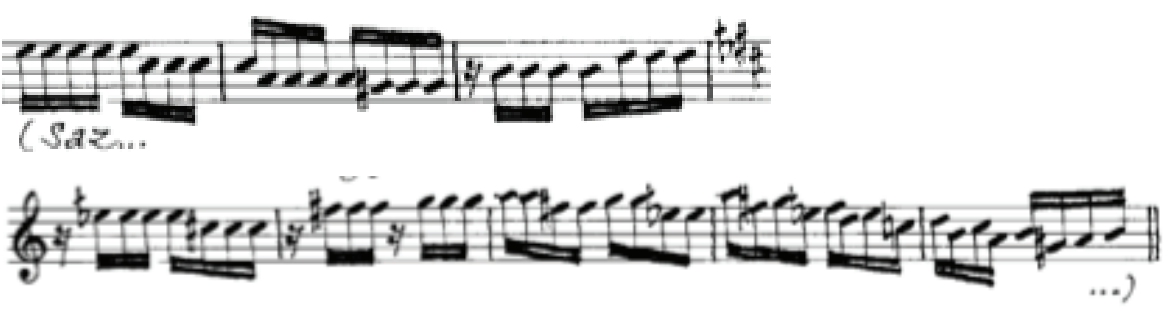

\section{Örnek 13. Kız Kulesi, Üçlü Aralık Hakimiyetiyle Tasarlanan Saz Payı 3}

\section{Kita Gelişme 2 (Orta Bölge)}

Saz payında kullanılan makamsal renklerin hazırlayıcılığı ile başlayan üçüncü kıtada Buselik ve Karcığar makamlarının kullanımı göze çarpmaktadır. Orta bölgedeki perdelerin kullanımıyla yine çargah ekseninde üretilen Buselik çekirdeğinin hemen ardından gelen Karcığar, ikinci ve üçüncü mısranın ezgi üretiminde kullanılmıştır. Bu bölüm yine Buselik ile sona ermiştir. Neva'da Hicaz ya da çargahda Nikriz olarak da değerlendirilebilecek olan bu kullanım, Buselik makamının Hüseyni ile olan irtibatı bağlamında ve ezgisel hareketi de tanımlaması bakımından Karcığar makamına geçki olarak değerlendirilmelidir. Cinuçen Tanrıkorur'un diğer bestelerinde de bu yapının ısrarlı bir şekilde kullanıldığı görülür. Karcığar ve Buselik çekirdeklerinin bu şekilde peşpeşe kullanımına, bestecinin "Gençlik Hülyaları" isimli Suzidil saz semaisinin son hanesi ve "Bir Buselik Dertleşme" isimli şarkısının nakarat girişi bu kullanımın tipik örneklerindendir.

1. misra $5-$

Mermerde mazi canlanır

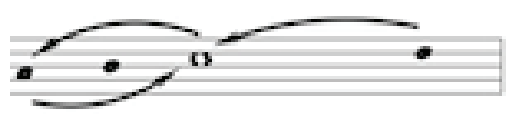

Buselik çekirdeği 2.misra

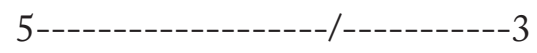

Zincir halkalar kanlanır

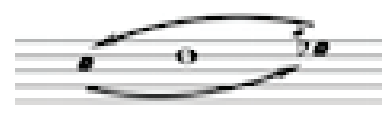

Yarım Nikriz çekirdeği (Karcığar) 
3.misra

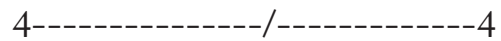

Pembe ufuk dumanlanır

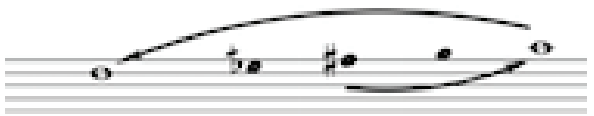

Neva'da Hicaz çekirdeği 4.misra

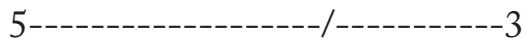

Ǘç beş bizanslı sal geçer

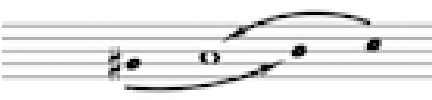

Buselik çekirdeği

\section{Saz Payı 4}

$\mathrm{Bu}$ saz payı eserin en tiz bölgesidir ve Şehnaz çekirdeği ile bestelenmiştir. Aşağıda görüldüğü gibi üçlü aralıklar yine ezgi yapısının motifini oluşturmaktadır.
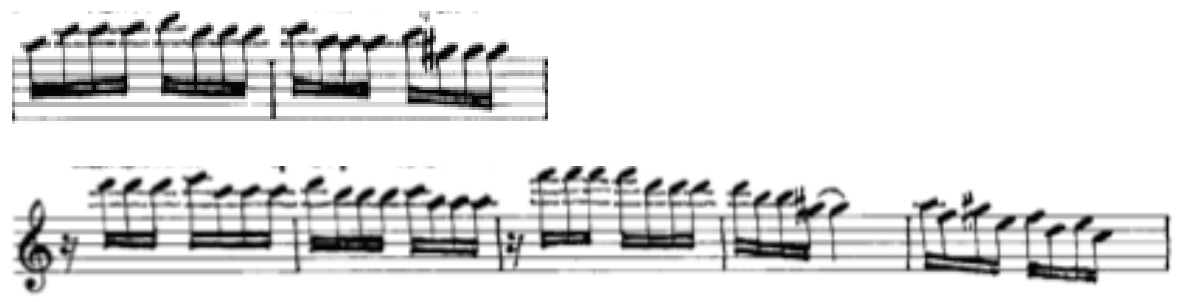

\section{Örnek 14. Kız Kulesi, Üçlü Aralık Hakimiyetiyle Tasarlanan Saz Payı 4}

\section{Kıta Gelişme 3 (Tiz Bölge)}

Bu bölümde de iki çekirdeği kullanılmıştır ve bu iki çekirdeğin birleşimi tek bir makamı, Şehnaz Buselik makamını oluşturmaktadır. Kıtanın başlangıç cümlesi tiz çargah ile olmuş ve perde perde inerek cümlenin bitişi hüseyni'de sonlanmıştır.

\section{1. misra}

6---------------------_---------2

Itırlar nakleder yazdan

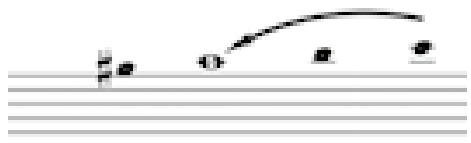

Şehnaz çekirdeği

\section{2.misra}

6-----------------------/---------2

Sükundan sohbetten sazdan

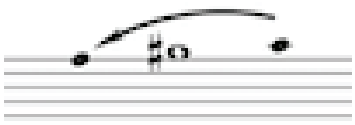

Şehnaz çekirdeği 
3.misra

5

Mevsim erguvan Boğaz'dan

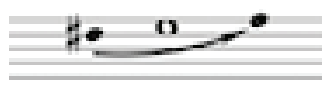

Hisar çekirdeği 4.misra

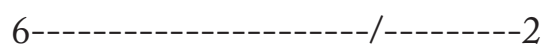

İstanbul'a dal dal geçer

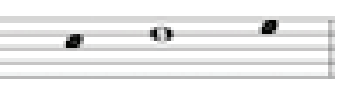

Hüseyni çekirdeği

\section{Kıta-Gelişme 4 (Orta Bölge)}

Bu mısranın duyuluşu gerdaniye perdesi etrafında merkezlenmiştir. Merkez perde olarak gerdaniyenin duyuruluşuyla bu yapı, Saba makamı rengine kısa bir gönderme olarak belirse de arkadan gelen ezgi yapısı Hisar çekirdeği ile sonlanmıştır. Bu kıtanın tamamıyla Hisar makamında bestendiğini görülmektedir. Hisar makamı yapısı içinde yer alan hüseyni'de Zirgüleli Hicaz yapısı, çekirdeğin Saba duyumu ile ortaya çıkmasına sebep olmuştur. Zira Zirgüleli Hicaz, perde düzeni bakımından üçüncü dereceyi merkez alarak ezgi ürettiğinde Saba makamı rengini meydana getirir. Hisar makamının kullandığı hareketlerden olan hüseyni üzerindeki Hüseyni makamının da karara gelirken dördüncü dereceyi pestleştirerek karar ettiği durumlar özellikle Halk müziği icralarında yer almaktadır. Aşağıdaki kısımda ezgisel hareketin Hisar makamı çekirdeğine dönmesi, bestecinin burada Hisar makamının seyir özelliklerini kullandığını düşündürmektedir. Bu işlenişin ardından gelen saz payı ise yalnızca Buselik makamı perdelerinden oluşmuştur. Hisar makamının işlenmesinin ardından saz payı ile yeniden Buselik makamına dönülmüş ve eser Hisar ile irtibatlı bir Buselik ile sona yaklaşmıştır.

Bu kıtanın son misrasında yedi kule zindanlarına gönderme yapılması ve bestecinin bu bölümü "Hisar" makamı ile bestelemesi, zindanların bulunduğu bölgenin surlarla çevrili oluşuna adeta bestecinin yaptığı bir gönderme gibidir.

\section{1.misra}

4------------------/----------------4

Kız kulesi billûr kuğu

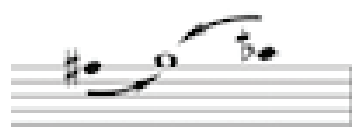

Hüseyni’de Saba çekirdeği 2.misra

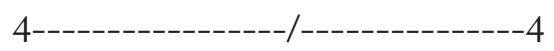

Hicran tüter buğu buğu(ah)

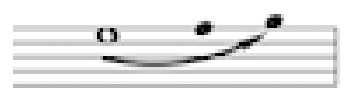

Kürdi çekirdeği 
3.misra

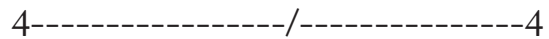

Nice canın boğulduğu

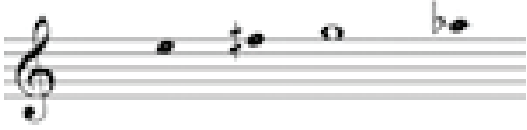

Hüseyni'de Saba cekirdeği 4.misra

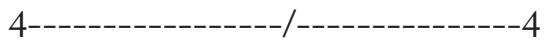

Zindan dilde misâl geçer

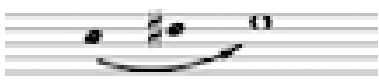

Hisar çekirdeğinden bir kısım

\section{Saz Payı 5}

Saz payı tamamen Buselik makamı ile bestelenmiş ve aşağıda görülen üçlü aralıkların kullandığı sekvenslerle herhangi bir makama geçki yapılmadan karara getirilmiştir.
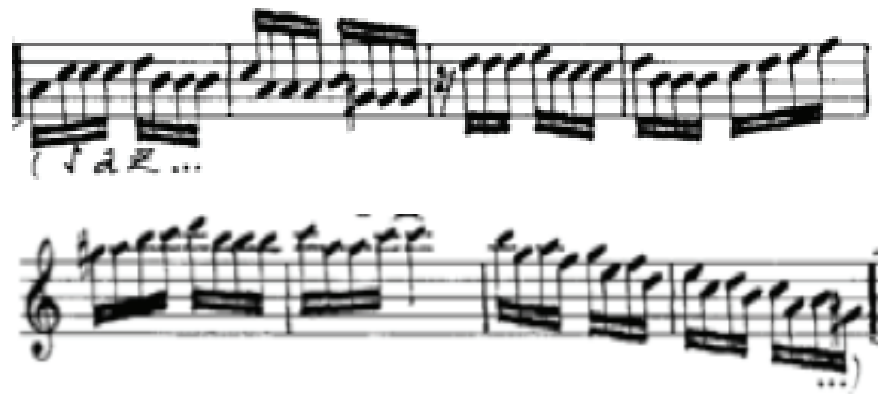

\section{Örnek 15. Kız Kulesi, Üçlü Aralık Hakimiyetiyle Tasarlanan Saz Payı 5}

\section{Kita -Sonuç (Karar Bölgesi)}

Son kıtanın ilk iki mısrası olan aşağıdaki dizeler, Buselik makamının karar ve orta bölgesinde yer alan perdelerle bestelenmiştir. Makamın merkez perdeleri olan dügah ve çargah ilk mısrada vurgulanmış ve ardından acem perdesi vurgusuyla son hece, makamın diğer bir merkez perdesi olan hüseyni perdesine bırakılmıştır.

Eserin son misrası olan bu kısımda ise Buselik makamı yapısına hisar perdesinin dahil edilerek eserin sonlandırıldığı görülür. Buselik makamının Hüseyni makamı ile olan irtibatı ve Hüseyni'nin ise Karcığar makamı ile iç içeliği bestecinin, bestecilik tercihinde bu şekilde bir yansıma bulmuştur. $\mathrm{Bu}-$ nunla birlikte hisar perdesinin evc perdesi kullanılmadan böyle bir kullanımı, Arazbar çekirdeği olarak da yorumlanabilir. 
1.misra

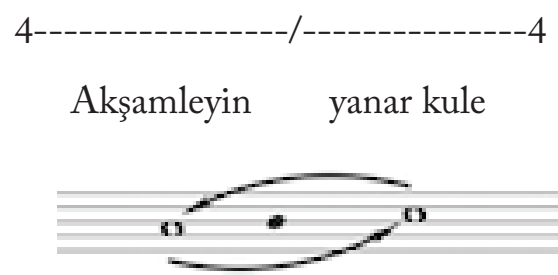

Buselik çekirdeği

3.misra

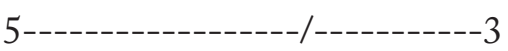

Atını sürer meçhûle

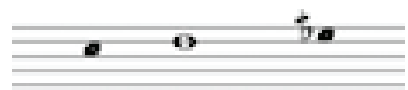

Karcığar çekirdeği 2.misra

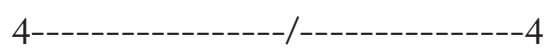

Dört ufuktan şule şule

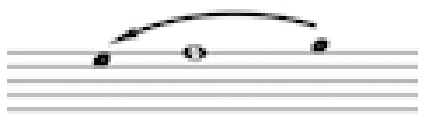

Acem çekirdeği

2.misra

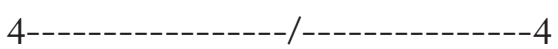

Koç yiğidim Battal geçer

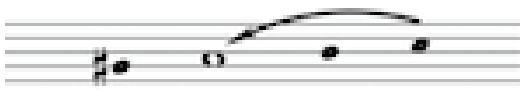

Buselik çekirdeği

Eser, 4. mısranın son kelimesinin kız, erkek ve saz partileri olarak çok seslendirilmesiyle tamamlanmıştır. Kullanılan perdeler ise Buselik makamının tüm ses sahasını içeren pest, orta ve tiz bölümlerine aittir. Eserdeki yenilikçi taraflardan biri olan bu pasajı aşağıda görmek mümkündür.

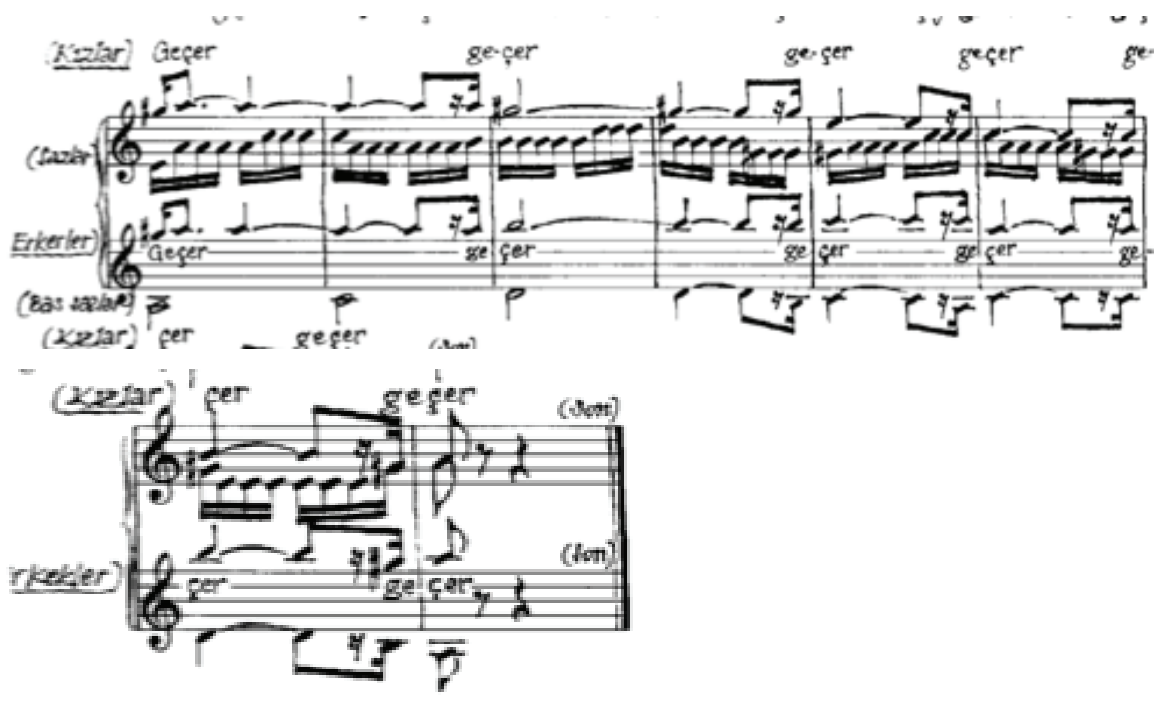

Örnek 16. Kız Kulesi, Çoksesli Final Pasajı 
Yapılan analizlerden görülen odur ki eserin genel yapısında işlenen Buselik makamı, geleneksel seyir anlayışı içinde kullanılmış ve bu yönüyle Tanrıkorur, geleneğe bağlı kalan bir nazari anlayışı tercih etmiştir. Bununla birlikte eser, kullanılan ezgi yapıları itibarıyla bestecinin karakterini taşıyan, özgün ve yenilikçi unsurları barındırmaktadır. Ezgi tasarımlarında, tonaliteyle ilişki kuran en dikkat çekici hareketler, üçlü aralıklarla ilerleyen sekvensli nağmelerde kendini göstermektedir. İlk kıta bütünüyle Buselik makamında bestelenmekle birlikte, diğer kıtalar Karcığar, Şehnaz ve Hisar'lı yapılarla bestelenmiştir. 


\section{SONUÇ}

Tanrıkorur'un yaşadığ1 yılların müzik dünyası, yakın geçmişin miras bıraktığı polemiklerle dolu bir ortamdır. Milli müzik politikaları odağındaki uzun süreli tartı̧malarda, Tanrıkorur makam müziğinin en güçlü savunucularından birisi olmuştur. Dergi ve gazetelere yazdığı sürekli yazılar ve karşıt fikirden olan sanat adamlarıyla girdiği sert tartı̧̧malar onun geleneğe olan sadakatinin söylemsel alandaki temsilleridir. Ancak onun bu yöndeki sadakati yalnızca söylemlerinde değil çok daha aktif ve etkin olarak müziksel üretimlerindedir. Aynı zamanda çok güçlü bir icracı da olan Tanrikorur, Türk tarihini ve medeniyetini temsil eden besteleri ile makam müziği geleneğinin bu yüzyılda nasıl yenilenebileceğini gösteren en dikkat çekici isim olmuştur. Bestecilik alanında ortaya koyduğu, atasözleri, destanlar, kur'ân lafızları, edebi alanda yüksek değer taşıyan şïrler gibi türler, bestecilik alanında daha önce kullanılmamış unsurlardır. Onun yüksek entelektüel kimliğini de temsil eden bu tercihler, geleneğe bağlı bir yenilenmenin de en güzel örnekleridir.

$\mathrm{Bu}$ çalı̧̧mada analizi yapılan Kız Kulesi isimli eser de bestecinin bu anlayışının tipik örneklerinden biridir. Feyzi Halıcı'nın hece vezniyle yazmış olduğu bu şiirde, yedi kule zindanlarına ve Battal Gazi'ye yapılan göndermeler, Tanrıkorur'un besteciliğinde Türk tarihinin seslerle yapılan tasvirine dönüşmüştür. Özellikle bu eserin beşinci kıtasında "zindan dilde misâl geçer" mısrasında yedi kule zindanlarına yaptığı atıf ve bu mısranın hisar çekirdeği ile bestelenmesi, bestecinin bu zindanların bulunduğu hisarlarla çevrili bölgeye yaptığı bir gönderme gibidir.

Tanrıkorur'un “yüksek deyişleri son musiki kurallarına göre işlemek”deki dehası, bir yandan Türk makam müziğine hizmet ederken diğer yandan da Türk kültür tarihine hizmet etmektedir. Yahya Kemal'in şiirlerine bestelerinde sıklıkla yer veren iki besteciden biri olan Tanrıkorur'un besteciliğinde, klasik şiir geleneğinden seçtiği çok sayıda eser bulunmaktadır. Kız Kulesi isimli Buselik fantezi de sözleri itibarıla bestecinin sıradışı güfte tercihini gösteren ve tasviri eser üretiminde alışlagelmiş konuların dışına çıkma anlayışını temsil eden üretimlerinden bir tanesidir.

Makamı kullanım noktasında ise gelenekteki Buselik makam yapısına bağlı kalmakla birlikte, bestecilikte kendi üslubunu ortaya koyan yenilikçi ve özgün nağme yapıları kullanmıştır. Geleneksel bestelerde çok fazla görülmeyen, yarı resitatif duyumu sağlayacak tartım yapıları, üçlü aralıkların sık kullanımı, eserin sonunda duyurulan çoksesli düzenlemeler gibi unsurlar da bu eserde Tanrıkorur'un yenilikçiliğini yansıtan yönlerdir.

Eser, gelenekle irtibatı sağlam bir yenilikçiliği temsil etmesi bakımından, Tanrıkorur bestelerinin her daim yol gösterici olacağının tipik bir örneğidir. 


\section{KAYNAKLAR}

Arslan, Fazlı (2015). "Musikinin Alaturkası mı Alafragası mı? İki Osmanlı Aydınının Orijinal Fikirleri: Mehmet Akif ve İsmail Fenni Bey”, İlahiyat Araştırmaları Dergisi 4, s. 141-151.

Ataman, Sadi Yaver (1991). Atatürk ve Türk Musikisi, Ankara: Kültür Bakanlığ1/1291, Atatürk Dizisi/31

Ayas, Güneş (2014). Mûsiki İnkılâbinıın Sosyolojisi. Klasik Türk Müziği Geleneğinde Süreklilik ve Değişim, Istanbul: Doğu Kitabevi.

Ayas, Güneş (2018). Müziğgi Boğan Gürültü, İdeolojinin Kıskacındaki “Mûsiki”. İstanbul: İthaki Yayınları.

Bayraktarkatal, Ertuğrul, Öztürk Okan Murat (2012). "Ezgisel Kodların Belirlediği Bir sistem Olarak Makam Kavramı: Hüseyni Makamının İncelenmesi”, Porte Akademik Müzik ve Dans Araștırmaları Dergisi (PAMDAD) 4, s. 24-59.

Güray, Cenk (2012). Bin Yılın Mirası-Makamı Var Eden Döngü: Edvar Geleneği-, İstanbul: Pan Yayıncilık.

Güray, Cenk, Karadeniz İsmet (2019). “Horasan'dan Keskin’e Bir Çığlık Muharrem Ertaş 'Kırat Bozlağı'nın Çok Katmanlı Analizi Üzerinden Orta Asya'dan Anadolu'ya Âşıklık Geleneğin'nin İzini Sürmek'”, Milli Folklor 31, 122, s. 76-93.

Harmanc1, Başak (2011). "Türk Musikisinde Seyir Kavramı ve Yeni Bir Form: Seyr-i Nâtık", Cukurova Üniversitesi İlâbiyat Fakültesi Dergisi 11, 2, s. 217-239

Hatipoğlu,Emrah(2019).MakamlarveTerkipler, (Erişim tarihi:19Ekim2019), https://play.google.com/books/reader?id=DnGqDwAAQBAJ\&pg=GBS. PA247

Kutluğ, Yakup Fikret (2000) Türk Musikisinde Makamlar, Yap1 Kredi Yayınlar1.

Kutluk, Fırat (2016). İllüzyon. Cumburiyetin Klasik Müzik Serüveni, İstanbul: $H_{2 \mathrm{O}}$ Kitap, Müzik ve Müzik Araştırmaları Dizisi.

Levendoğlu, Oya (2018). “Darü’l-Elhândan Günümüze Nağmelerin Evleri: Bir Medeniyet Serüveni”, Kuruluşunun Yüzüncü Yılında Dârül-Elhân’a Armağan, Ankara: Atatürk Kültür Merkezi Başkanlığı Yayını. s.117-137. 
Özdemir, A. Tolga, Levendoğlu N. Oya (2011). "Ud İcra Geleneğinde Cinuçen Tanrıkorur Ekolünün Uzzal Taksim Üzerinden Yansımaları”, İnönü Üniversitesi Sanat ve Tasarm Dergisi, I. s. 325-337.

Öztürk, Okan Murat (2016). "Milli Musiki Ütopyası: "Halk Ruhunu Garp Fenniyle Terkib Etmek”, İllüzyon. İstanbul: H2o Kitap.

Sağbaş, B. Reha Cinuçen Tanrıkorur Beste Külliyatı. Editör: B. Reha Sağbaş, Ankara: Atatürk Kültür Merkezi Başkanlığ̣1 Yayını.

Şimşek, Hikmet (1997). "Bay Cinuçen Tanrıkorur'un İki Yazısına Bir Cevap", 279: 7-20

Şimşek, Hikmet (1997). "Ve Bir Mektup”, Orkestra 279, s. 21-23

Şimşek, Hikmet (1998). "Bir Açıllama”, Orkestra 289, s. 52-53

Tanrıkorur Cinuçen (1968). “Tek Cümle ile Arel”, Musiki Mecmuası 234, s. 8. Tanrıkorur Cinuçen (1978). "Atatürk Devrimleri ve Musikimiz", Musiki Mecmuası 348, s. 15-17.

Tanrıkorur Cinuçen (2001). “Müzikte Evrensellik II”, Biraz da Müzik. Zaman Kitap.

Üngör, Ethem Ruhi (1968). “Arelcilik Nedir?”., Musiki Mecmuası 234, s. 13. 
Ek:1

Kız Kulesi

(Sadeleștirme)
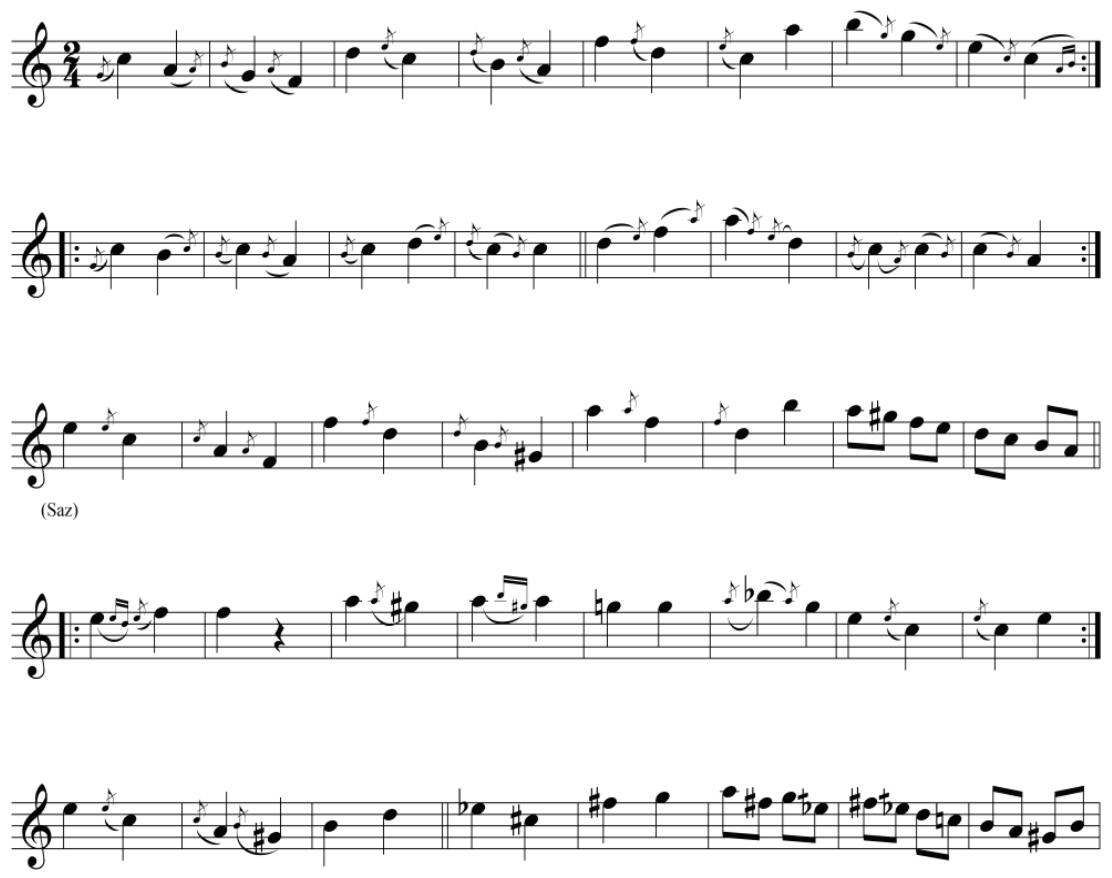

(Saz)
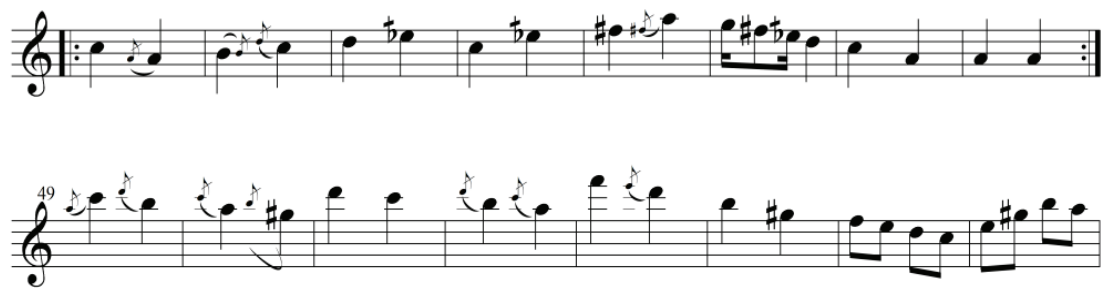

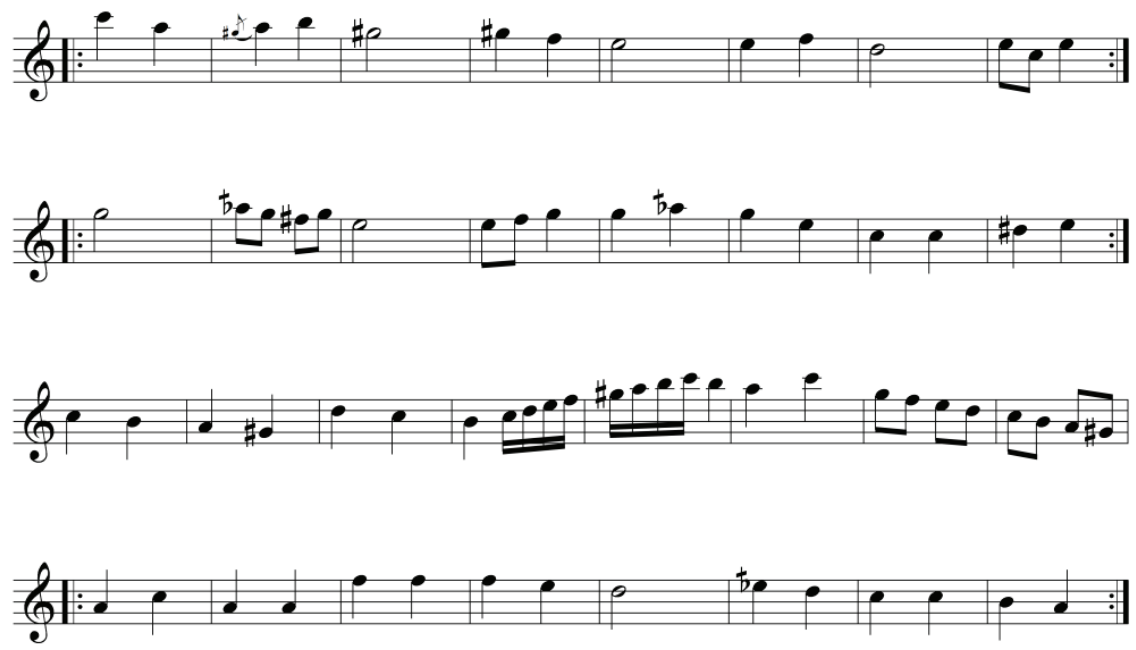
(Saz)

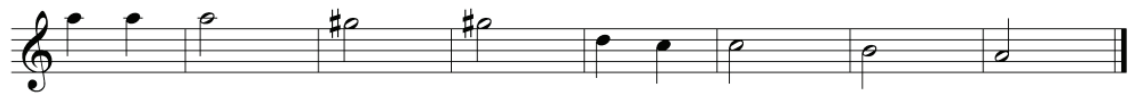


Ek:2
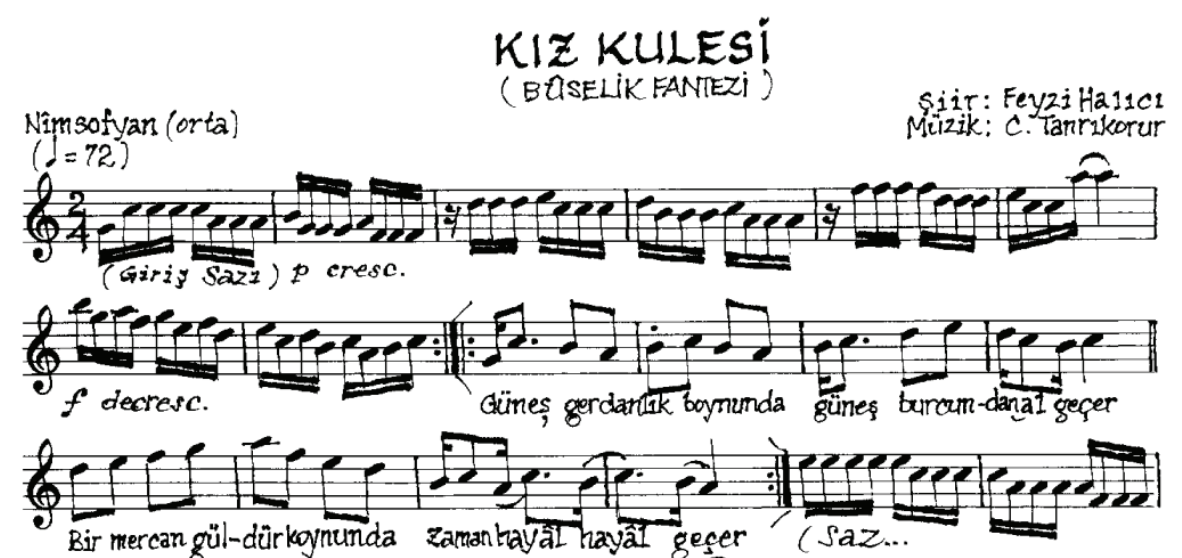

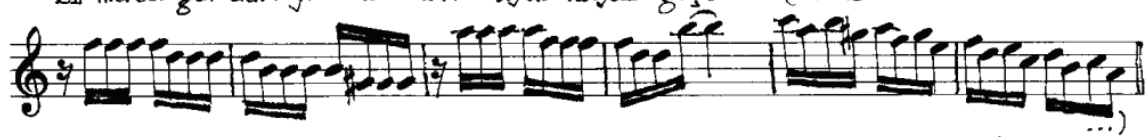

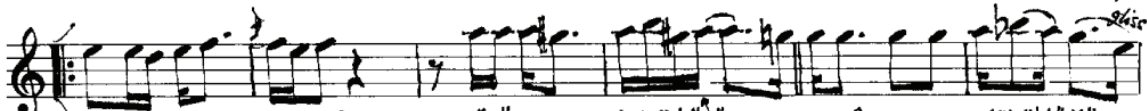
Yosmasuların köpüğü Goözüsarar büyübüyü semâ rengin döküldüğü

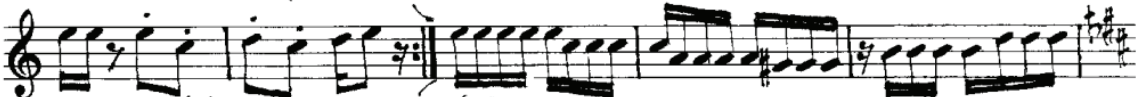
suda sandal sandal geçer (Saz...

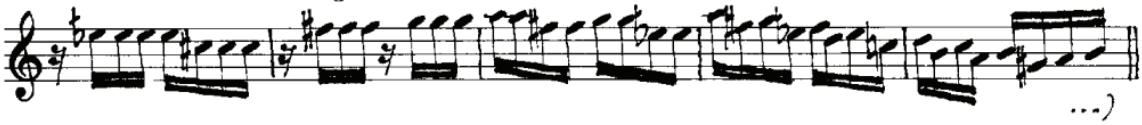

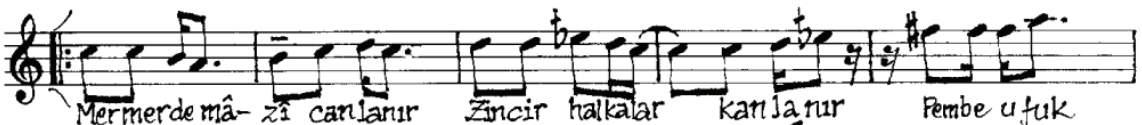

(6) if dumanlanir us-bes Bzans-11 salgeser.

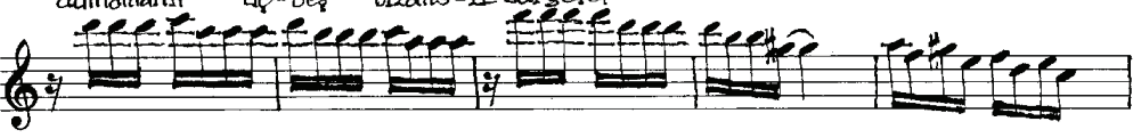

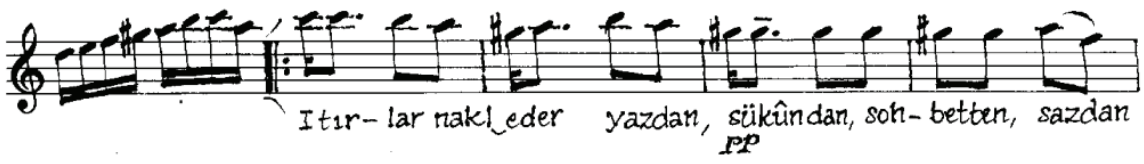

18.7.1993 Besteno. 284 

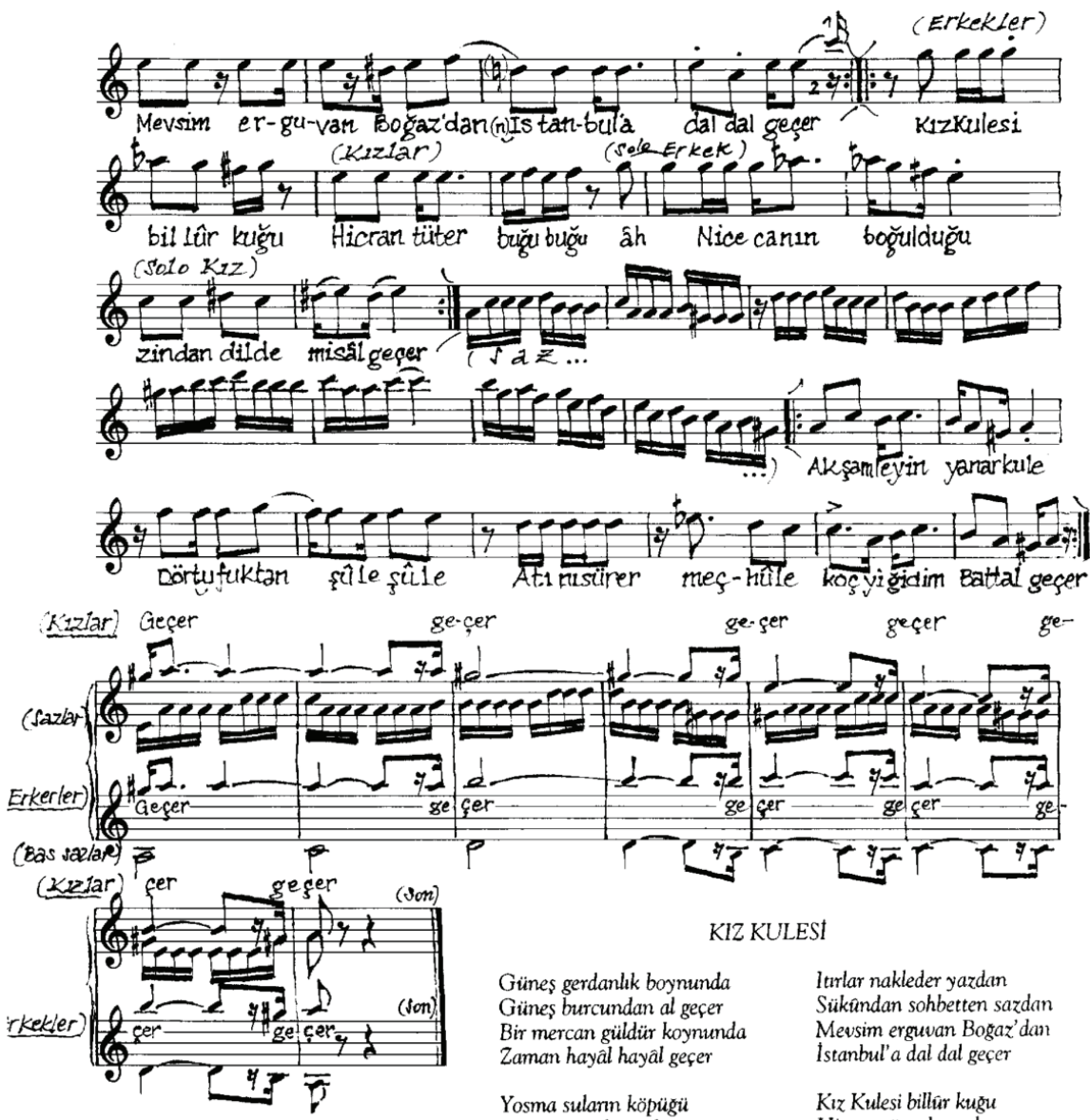
ge-çer ge-çer geçer ge-

Günes gerdanlik boynunda Günes burcundan al geçer Bir mercan güldür koynunda Zaman hayâl hayâl geçer

Yosma sularn köpügü Gözü sarar büyü büyü

Semâ rengin döküldügü

Suda sandal sandal geçer

Mermerde mâzi canlanır Zincir halkalar kanlantr

Pembe ufuk dumanlanur Ü̧-bes Bizansh sal geçer
Itrlar nakleder yazdan Sükûndan sohbetten sazdan Meusim erguvan Bogaz'dan Istanbul' a dal dal geçer

Kiz Kulesi billûr kugu Hicran tüter buğu buğu Nice canin boğulduğu Zindan dilde misal geçer

Aksamleyin yanar kule Dört ufuktan şale şâle Atmı sürer meçûule

Koç yigidim Battal geçer

Feyzi Halıı 